Review article

Food Quality and Functionality Section

\title{
Phenolic Compounds from Apples: Reviewing their Occurrence, Absorption, Bioavailability, Processing, and Antioxidant Activity - a Review
}

\author{
Matgorzata Starowicz ${ }^{1 *} \odot$, Bohdan Achrem-Achremowicz ${ }^{2}$, Mariusz K. Piskuta $^{1}{ }^{\oplus}$, Henryk Zieliński $^{1} \odot$ \\ ${ }^{1}$ Department of Chemistry and Biodynamics of Food, Division of Food Sciences, Institute of Animal Reproduction and Food \\ Research of the Polish Academy of Sciences, ul. Tuwima 10, 10-748 Olsztyn, Poland \\ ${ }^{2}$ Department of Technology and Evaluation of Plant Products, Faculty of Biology and Agriculture, \\ University of Rzeszów, ul. Zelwerowicza 4, 35-601 Rzeszów, Poland
}

Key words: apples, bioactive compounds, phenolic compounds, functional properties, geographic origin, cultivars, production influence

This review summarises the research on phenolic compounds in apples in relation to their geographical origin, cultivars, technological processes, and human health effects due to their antioxidant activity and bioavailability. Apples are popular among consumers and are known as a rich source of vitamins, minerals, and biologically active compounds. In this review article, we have focused on their phenolic compounds. Some epidemiological studies have confirmed the protective effects of apples against chronic diseases, which can be linked to the high content of phenolics in plant tissues and their bioavailability. However, according to the available literature, the geographical origin and variety of apples influence the content of these bioactive compounds and are highly related to their antioxidant activity fluctuation. The gathered studies have confirmed that the choice of polyphenol-rich raw material as well as proper processing are important to achieve high-quality fruit-based products with a high content of antioxidants after a few stages of production. It was proven that the processing of apples could significantly modify the content of phenolics in the finished products, including juices, concentrates, vinegars, and ciders. For instance, the use of high pressure or vacuum has been proposed as a highly potent solution in inhibiting flavonoid degradation during intensive processing. Moreover, several methods have been screened to monitor the phenolic content and antioxidant activity of apple samples, based on spectrophotometry, HPLC, LC-MS, and LC-MS/MS techniques for chemical compound separation and identification. The main assumptions of these techniques and results obtained are described in this review.

\section{INTRODUCTION - THE PROTECTIVE EFFECTS OF BIOACTIVE COMPOUNDS FROM FRUITS AND VEGETABLES IN HUMANS}

Data published by the World Health Organization (WHO) show that low consumption of fruits and vegetables might be the reason for the increased incidence of chronic diseases, and could be the cause of $14 \%$ of deaths from gastrointestinal cancers, $11 \%$ of those from coronary heart disease, and 9\% of those from strokes [WHO, 2009; Arts \& Hollman, 2005]. One of the hypotheses is that vegetables and fruits contain high amounts of biologically active compounds eliciting protective effects against lifestyle-related diseases [Arts \& Hollman, 2005]. This effect might be due to the antioxidant properties of certain compounds. Antioxidants inhibit oxidation reactions, thus scavenging oxygen free radicals formed upon these reactions. Free radicals can bind proteins, damage lipids of cell membranes, or disrupt the structure of nucleic acids. They are naturally counteracted by the human organism; however, this natural balance might be upset by illnesses, stress, excessive consumption of highly-processed foods,

\footnotetext{
* Corresponding Author: Tel.: +48 895234639; Fax: +48 895234693;

E-mail: m.starowicz@pan.olsztyn.pl (Dr. M. Starowicz)
}

and high environmental pollution. The consumption of fruits and vegetables is highly recommended to support the body in this respect. The main antioxidants found in fruits and vegetables are $\mathrm{A}, \mathrm{E}$, and $\mathrm{C}$ vitamins; $\beta$-carotene; lycopene; and a diverse group of compounds named phenolics. Therefore, it is hard to select one specific compound responsible for health benefits. That is why, Ohr [2004] stated that "scientists are currently studying how mixtures of antioxidants ... work together. They are looking for synergistic effects among individual antioxidants."

The most important group of antioxidants is the phenolic compounds (Figure 1). They are organic chemical compounds with at least one phenol unit, represented by, i.a., tannins (hydrolysable and condensed), flavonoids, and lignans. Phenolic compounds can be found in a variety of plant species. Their high content is correlated with antioxidant activity, which decreases the risk of coronary disease and protects against neurodegeneration [Giacalone et al., 2015]. The positive effect of flavonoids on memory improvement was also studied [Whyte \& Williams, 2011]. Of 12 epidemiological surveys about coronary heart disease risk assessment compared by Arts \& Hollman [2005], seven demonstrated the protective effects of a diet enriched with polyphenols. An inverse relationship has also been determined between poly- 


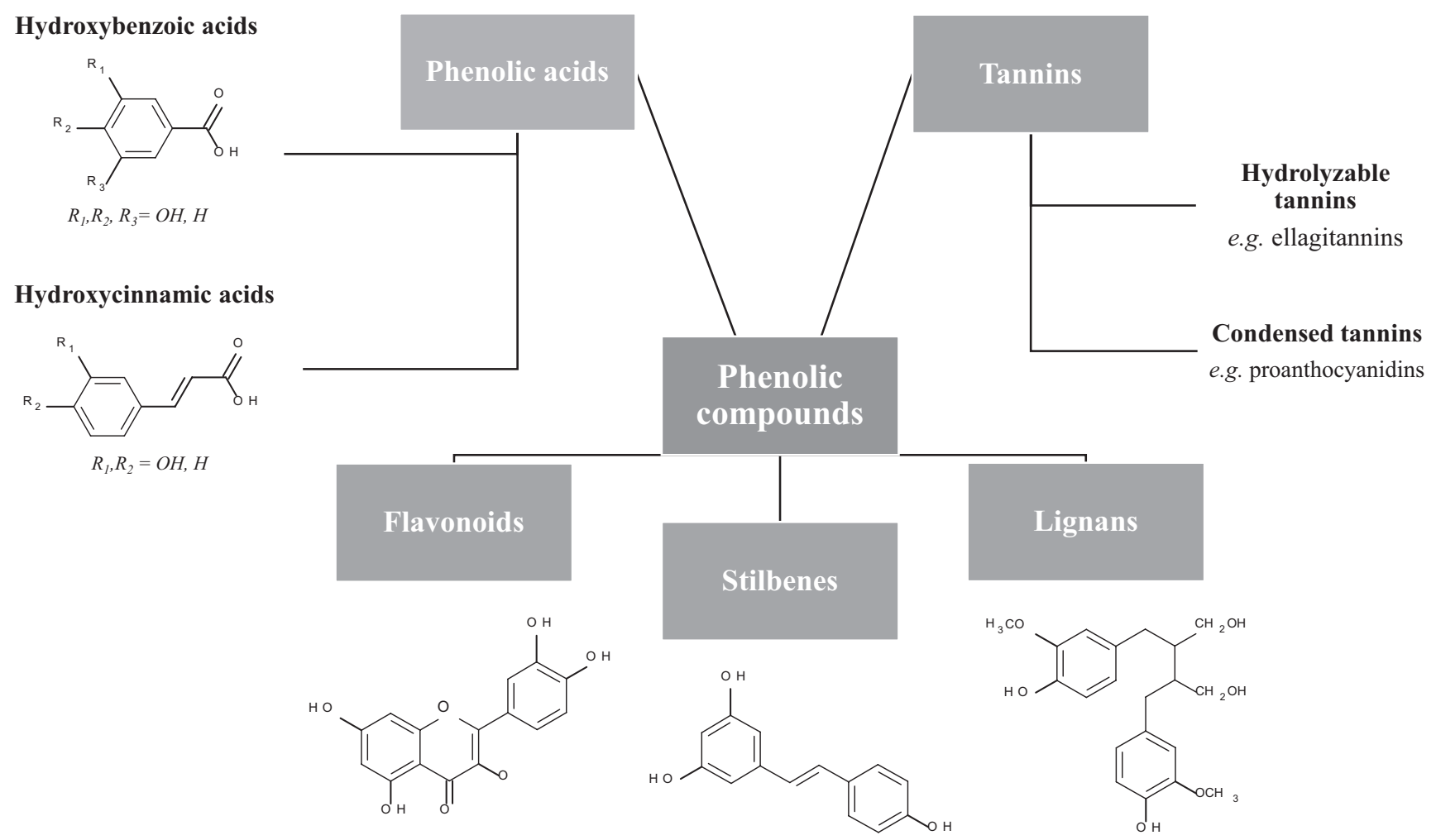

FIGURE 1. Representatives of phenolic compounds with their chemical structures.

phenol intake and stroke and breast cancer risk [Bosetti et al., 2005; Knekt et al., 2002]. In turn, Jiao et al. [2019] have demonstrated that phenolics affect obesity by modulating the gut microbiota and prebiotic agents. Moreover, the anti-inflammatory properties of flavonoids were discussed by Maleki et al. [2019], who suggested that the possible mechanism of their action is by inhibiting enzyme activity and transcription factors responsible for inflammation. In epidemiological studies conducted on the Finnish population ( $>10,000$ people), it was proven that flavonoid intake might be crucial for decreasing the risk of development of chronic diseases [Knekt et al., 2002]. Also, in clinical studies, a positive correlation was observed between flavonoid administration and the progress of type 2 diabetes [Guo et al., 2019]. Finally, a positive effect of nutritional supplementation with flavonoids was seen in the research on skeletal muscle atrophy to prevent oxidative stress-induced muscle waste [Salucci \& Falcieri, 2020].

One of the most affordable fruit-based products on the market is juice. Juices have been proved to contain a high number of antioxidants, such as vitamin $\mathrm{C}$, and to be rich in varied polyphenols [Jacob et al., 2008; Martí et al., 2009]. Therefore, it has been experimentally confirmed that the polyphenols from grape juice prevent heart disease and that compounds with high antioxidant activity from berries or apple juice inhibit hypercholesterolemia [Habanova et al., 2019]. In another example, juice from pineapples, oranges, and grapefruits was seen to be a rich source of folic acid derivatives, which help prevent nervous system diseases and malformations, such as spina bifida. In turn, cranberry juice has been shown to decrease urinary tract infections [Jepson et al., 2004].

Among the polyphenols, considerable attention has been paid to flavonoids, the intake of which varies from 60 to $600 \mathrm{mg}$ per day among different dietary patterns. Ample studies have focused on determining their content in different food products using novel methodologies and advanced equipment. Today, their bioavailability in the human body is a topic related to phenolic compounds' influence on human health [Manach et al., 2005].

\section{APPLE PHENOLIC COMPOUNDS - PROFILE AND INTAKE}

Apples are a rich source of flavonoids, including flavones, flavanols, anthocyanins, and dihydrochalcones (Figure 2). The major individual flavonoids in apples are quercetin and its glycosides, (-)-epicatechin, (+)-catechin, and phloridzin and its derivatives [Lee et al., 2003; Francini \& Sebastiani, 2013]. Cyanidin glycosides can be found only in apples of red varieties. Other apple polyphenols are procyanidins - the oligomers of (-)-epicatechin and (+)-catechin, with their content in apple fresh weight ranging from 38 to $154 \mathrm{mg}$ [Hellstrom et al., 2009]. Phenolic acids, e.g., chlorogenic acid, are also present in apple flash and skin. However, the quantitative and qualitative profile of phenolic compounds found in apples differs depending on their variety, country of origin, and special pre-treatment, which is summarised in Table 1.

Zhang et al. [2019] reported that the positive effect of phenolic content and composition might be due to the pol- 
lination of apples with quince pollen. A significant increase in (+)-catechin, (-)-epicatechin, chlorogenic acid, phlorizin, quercetin, and quercetin 3-O-galactoside contents was obtained by this modification.

Only a part of phenolic compounds is found in the free form in plant tissues, and most are bound to cell wall components. Important is that apples have the highest portion of free phenolics when compared to other fruits [Sun et al., 2002]. The apples' bound phenolics are less bioavailable than free phenolics since they need to be released from the food matrix during digestion [Williamson et al., 2018]. Therefore, an important aspect of research is to study phenolics occurrence in natural food products and then to determine their intake by consumers. Apples, blackcurrants, strawberries, raspberries, chokeberries, cranberries, blackberries, plums, apricots, pomegranates, oranges, pineapples, and grapefruits are known to be the richest sources of polyphenols [Calderón-Oliver \& Ponce-Alquicira, 2018]. Their consumption is estimated to range from 100 to $200 \mathrm{~g}$ per day. Apples provide approx. $22 \%$ of polyphenols in the diet [Scalbert \& Williamson, 2000]. An apple portion contains $400 \mathrm{mg}$ of polyphenols, whereas the average portion of pears or grapes provides $300 \mathrm{mg}$ of polyphenols, and a portion of cranberries, cherries or blueberries provides 200-400 mg [Scalbert \& Williamson, 2000]. In general, the intake of polyphenolic compounds varies widely among populations with the average approximating $1 \mathrm{~g}$ per day [Scalbert \& Williamson, 2000]. For example, the main source of flavonoids in a diet of the Australian population is soy and its products, whereas $55.2 \%$ of total flavonoids come from non-alcoholic beverages in a diet of the French population [Del Bo et al., 2019]. In many countries (e.g., Poland), tea and fruits are also a common source of flavonoids in the diet. According to data selected by Murphy et al. [2019], flavonoid intake also varies by gender: women in Australia consume a higher amount of flavonoids than men: 659 vs. $566 \mathrm{mg}$ per day. The interest in purchasing natural food products with a high flavonoid content by consumers might be driven by their positive effects on human health.

\section{APPLE PHENOLIC COMPOUNDS - THE BIOLOGICAL EFFECTS}

As mentioned in the Introduction section, dietary phenolics can play a positive role in reducing the risk of development of chronic diseases associated with oxidative stress. The biological effects of apple phenolic compounds are also of interest. Flavonoids extracted from apple peel were implicated in the suppression of breast cancer and the growth of carcinogenic cells in the bronchi [George \& Rupasinghe, 2017; Loung et al., 2019]. In turn, Zielińska et al. [2019] proved the potential benefits of apple-derived polyphenols in modulating inflammation at the intestinal level. Apple extracts can also regulate carbohydrate metabolism through the inhibition of $\alpha$-glucosidase activity, thereby potentially reducing the risk of type 2 diabetes development [Raphaelli et al., 2019]. The newest research from Zou et al. [2020] showed that apple phenolics might be effective in the prevention of obesity via promoting brown adipogenesis. There is no clear evidence as to whether apple flavonoids protect lipids and proteins in plasma and decrease LDL cholesterol level [Zou et al., 2020]. Zeng et al. [2020] explained, with the example of apple proanthocyanidins, that the hypocholesterolemic activity of polyphenols might be related to their ability to bind cholesterol. In their in vitro study, tannins were potent

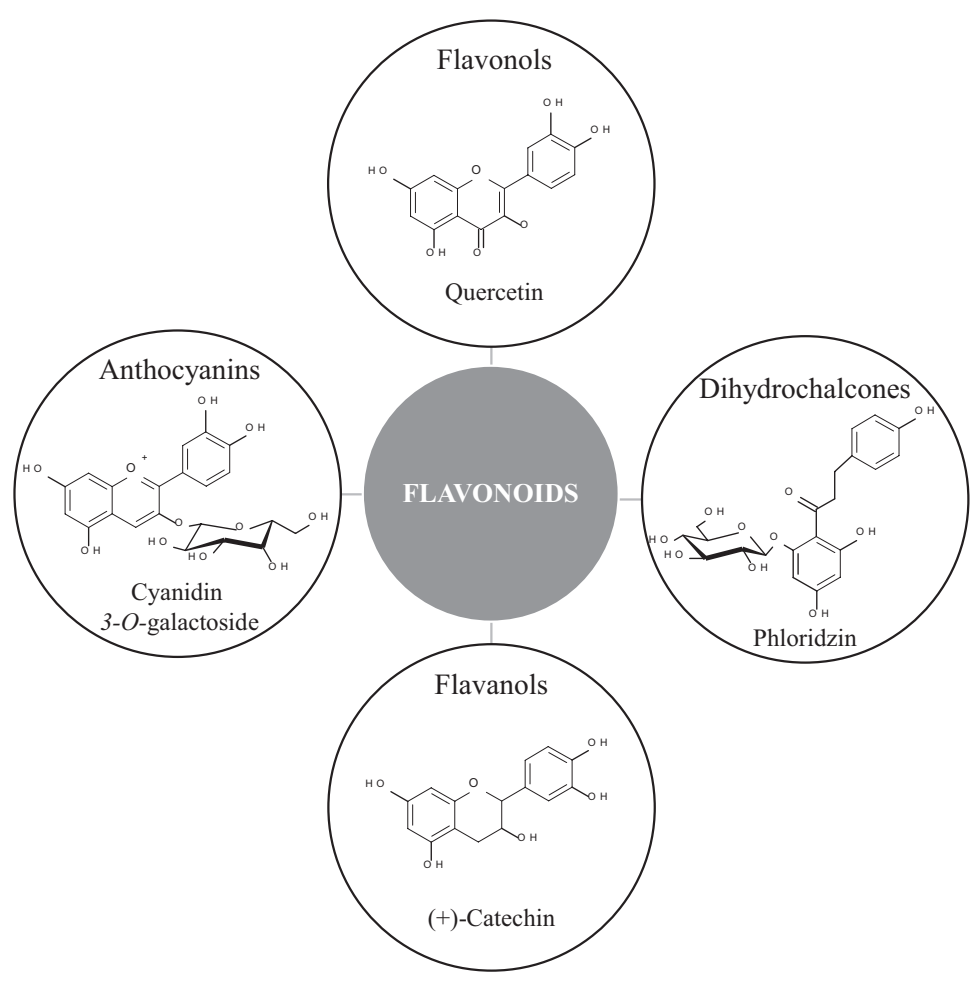

FIGURE 2. Flavonoid classes with examples of each class and their structure. 
TABLE 1. The summary of latest studies about major phenolic compounds found in apples according to variety, country of origin, and special pre-treatment.

\begin{tabular}{|c|c|c|c|c|c|}
\hline Material & $\begin{array}{l}\text { Country } \\
\text { of origin }\end{array}$ & $\begin{array}{l}\text { Apple } \\
\text { variety }\end{array}$ & Content of major phenolic compounds & Main remarks & Reference \\
\hline Apple peel & Croatia & $\begin{array}{l}\text { Apistar' } \\
\text { 'Bobovac', } \\
\text { 'Božićnica' }\end{array}$ & $\begin{array}{l}\text { (-)-epicatechin: } \mathbf{1 1 9 . 5} \mathrm{mg} / 100 \mathrm{~g} \text { DW } \\
\text { (-)-epicatechin: } \mathbf{1 3 1 . 8} \mathrm{mg} / 100 \mathrm{~g} \text { DW } \\
\text { (-)-epicatechin: } \mathbf{5 0 . 4} \mathrm{mg} / 100 \mathrm{~g} \mathrm{DW}\end{array}$ & $\begin{array}{l}\text { The content } \\
\text { of phenolics } \\
\text { in peel differs } \\
\text { among varieties }\end{array}$ & $\begin{array}{c}\text { Loncarić } \\
\text { et al. [2020] }\end{array}$ \\
\hline Raw apple & & & $\begin{array}{c}\text { procyanidin } \mathrm{B}_{2}: \mathbf{9 1 . 5 5} \mathrm{mg} / 100 \mathrm{~g} \mathrm{DW} \\
(-) \text {-epicatechin: } \mathbf{7 6 . 3 0} \mathrm{mg} / 100 \mathrm{~g} \mathrm{DW} \\
\text { quercetin } 3-O \text {-rhamnoside: } \mathbf{8 . 3 5} \mathrm{mg} / 100 \mathrm{~g} \mathrm{DW}\end{array}$ & \multirow{4}{*}{$\begin{array}{l}\text { High-pressure } \\
\text { releases flavonoids } \\
\text { from the matrix }\end{array}$} & \multirow{4}{*}{$\begin{array}{l}\text { Fernández-Jalao } \\
\text { et al. [2019] }\end{array}$} \\
\hline $\begin{array}{l}\text { High-pressure } \\
\text { treated apple } \\
\left(400 \mathrm{MPa} \text { at } 35^{\circ} \mathrm{C}\right. \\
\text { for } 5 \mathrm{~min})\end{array}$ & Spain & 'Golden Delicious' & $\begin{array}{l}\text { procyanidin } \mathrm{B}_{2}: \mathbf{9 5 . 0 2} \mathrm{mg} / 100 \mathrm{~g} \mathrm{DW} \\
\text { (-)-epicatechin: } \mathbf{7 3 . 0 8} \mathrm{mg} / 100 \mathrm{~g} \text { DW } \\
\text { quercetin } 3-O \text {-rhamnoside: } \mathbf{1 1 . 0 8} \mathrm{mg} / 100 \mathrm{~g} \mathrm{DW}\end{array}$ & & \\
\hline Raw apple & & & $\begin{array}{c}\text { procyanidin } \mathrm{B}_{2}: \mathbf{7 4 . 5 1} \mathrm{mg} / 100 \mathrm{~g} \mathrm{DW} \\
(-) \text {-epicatechin: } \mathbf{6 7 . 8 9} \mathrm{mg} / 100 \mathrm{~g} \mathrm{DW} \\
\text { quercetin 3- } O \text {-rhamnoside: } \mathbf{9 . 7 3} \mathrm{mg} / 100 \mathrm{~g} \mathrm{DW}\end{array}$ & & \\
\hline $\begin{array}{l}\text { High-pressure } \\
\text { treated apple } \\
\left(600 \mathrm{MPa} \text { at } 35^{\circ} \mathrm{C}\right. \\
\text { for } 5 \mathrm{~min})\end{array}$ & Italy & 'Golden Delicious' & $\begin{array}{l}\text { procyanidin } \mathrm{B}_{2}: \mathbf{1 0 3 . 5 7} \mathrm{mg} / 100 \mathrm{~g} \mathrm{DW} \\
(-) \text {-epicatechin: } \mathbf{9 8 . 5 8} \mathrm{mg} / 100 \mathrm{~g} \mathrm{DW} \\
\text { quercetin } 3-O \text {-rhamnoside: } \mathbf{2 0 . 1 5} \mathrm{mg} / 100 \mathrm{~g} \text { DW }\end{array}$ & & \\
\hline Raw apple & Italy & $\begin{array}{l}\text { 'Golden Delicious' } \\
\text { organic }\end{array}$ & $\begin{array}{c}\text { (-)-epicatechin: } \\
\text { Before frozen storage: } \mathbf{1 9 . 3} \mathrm{mg} / 100 \mathrm{~g} \text { DW } \\
\text { Dipped: } \mathbf{2 1 . 2} \mathrm{mg} / 100 \mathrm{~g} \mathrm{DW} \\
\text { Vacuumed with lemon juice: } \mathbf{1 8 . 1} \mathrm{mg} / 100 \mathrm{~g} \\
\text { After frozen storage: } \mathbf{1 9 . 4} \mathrm{mg} / 100 \mathrm{~g} \text { DW } \\
\text { Dipped: } \mathbf{1 6 . 7} \mathrm{mg} / 100 \mathrm{~g} \mathrm{DW} \\
\text { Vacuumed with lemon juice: } \mathbf{1 8 . 0} \mathrm{mg} / 100 \mathrm{~g} \\
(-) \text {-epicatechin: } \\
\text { Before frozen storage: } \mathbf{1 9 . 6} \mathrm{mg} / 100 \mathrm{~g} \text { DW } \\
\text { Dipped: } \mathbf{2 0 . 0} \mathrm{mg} / 100 \mathrm{~g} \text { DW } \\
\text { Vacuumed with lemon juice: } \mathbf{2 5 . 4} \mathrm{mg} / 100 \mathrm{~g} \\
\text { After frozen storage: } \mathbf{1 5 . 0} \mathrm{mg} / 100 \mathrm{~g} \text { DW } \\
\text { Dipped: } \mathbf{1 6 . 9} \mathrm{mg} / 100 \mathrm{~g} \mathrm{DW} \\
\text { Vacuumed with lemon juice: } \mathbf{1 9 . 0} \mathrm{mg} / 100 \mathrm{~g}\end{array}$ & $\begin{array}{l}\text { Vacuum pre- } \\
\text { treatment } \\
\text { method in acid } \\
\text { environment } \\
\text { inhibits } \\
\text { degradation } \\
\text { of flavonoids } \\
\text { during storage }\end{array}$ & $\begin{array}{l}\text { Santarelli } \\
\text { et al. [2020] }\end{array}$ \\
\hline Raw apple & Japan & 'Red Delicious' & 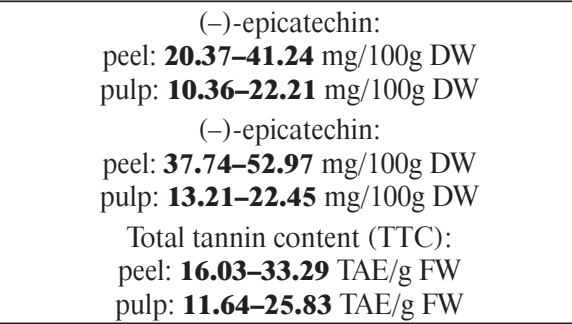 & $\begin{array}{c}\text { The profile } \\
\text { of phenolics differs } \\
\text { among apple } \\
\text { parts and growing } \\
\text { locations at } \\
\text { different altitudes }\end{array}$ & $\begin{array}{c}\text { Dhyani } \\
\text { et al. [2018] }\end{array}$ \\
\hline Crabapple & China & $\begin{array}{l}\text { M. micromalus } \\
\text { 'Haihongguo' }\end{array}$ & $\begin{array}{c}\text { procyanidin } \mathrm{B}_{1}: \mathbf{1 0 3 . 5 7} \mathrm{mg} / \mathrm{kg} \mathrm{DW} \\
\text { (-)-epicatechin: } \mathbf{3 6 . 3 4} \mathrm{mg} / \mathrm{kg} \mathrm{DW} \\
\text { phloridzin: } \mathbf{2 4 . 5 7} \mathrm{mg} / \mathrm{kg} \mathrm{DW} \\
\text { hyperin: } \mathbf{7 2 . 0 9} \mathrm{mg} / \mathrm{kg} \mathrm{DW} \\
\text { isoquercitrin: } \mathbf{2 5 . 0 1} \mathrm{mg} / \mathrm{kg} \mathrm{DW} \\
\text { procyanidin } \mathrm{B}_{1}: \mathbf{8 4 7 . 8 8} \mathrm{mg} / \mathrm{kg} \mathrm{DW} \\
(+) \text {-catechin: } \mathbf{4 3 0 . 9 6} \mathrm{mg} / \mathrm{kg} \mathrm{DW} \\
\text { procyanidin } \mathrm{B}_{2}: \mathbf{2 0 3 . 4 7} \mathrm{mg} / \mathrm{kg} \mathrm{DW} \\
(-) \text {-epicatechin: } \mathbf{1 2 2 0 . 7 6} \mathrm{mg} / \mathrm{kg} \mathrm{DW} \\
\text { phloridzin: } \mathbf{9 4 . 4 2} \mathrm{mg} / \mathrm{kg} \mathrm{DW} \\
\text { hyperin: } \mathbf{7 2 . 0 9} \mathrm{mg} / \mathrm{kg} \mathrm{DW} \\
\text { isoquercitrin: } \mathbf{4 9 . 0 6} \mathrm{mg} / \mathrm{kg} \mathrm{DW} \\
\text { procyanidin } \mathrm{B}_{1}: \mathbf{1 5 3 4 . 7 8} \mathrm{mg} / \mathrm{kg} \mathrm{DW} \\
(+)-\text { catechin: } \mathbf{1 3 2 6 . 3 3} \mathrm{mg} / \mathrm{kg} \mathrm{DW} \\
\text { procyanidin } \mathrm{B}_{2}: \mathbf{2 1 5 1 . 8 6} \mathrm{mg} / \mathrm{kg} \mathrm{DW} \\
(-) \text {-epicatechin: } \mathbf{2 7 2 7 . 6 9} \mathrm{mg} / \mathrm{kg} \mathrm{DW} \\
\text { cyanidin 3- } O \text {-galactoside: } \mathbf{1 9 0 . 1 7} \mathrm{mg} / \mathrm{kg} \mathrm{DW}\end{array}$ & $\begin{array}{l}\text { Total polyphenol } \\
\text { content } \\
\text { is the highest } \\
\text { in apple cultivar } \\
\text { 'Red splendor' }\end{array}$ & $\begin{array}{c}\text { Han } \\
\text { et al. [2019] }\end{array}$ \\
\hline
\end{tabular}

DW - dry weight; FW - fresh weight; TAE - tannic acid equivalent. 
to precipitate cholesterol via interactions of ions and hydrophobic and intermolecular hydrogen bonds. Moreover, Hamauzu et al. [2005] demonstrated apple phenolic compounds to be significant inhibitors of the influenza viral activity. Then, in later research, Pastene et al. [2009] observed suppressed Helicobacter pylori urease activity after incubation with apple peel extracts, which suggests that apple phenolic compounds have a strong gastro-protective effect. It was also proved that apple extracts had an antibacterial effect against Gram-positive bacteria [Pires et al., 2018].

Flavonoids are metabolized in vivo, which suggests that they have a low impact on the antioxidant activity in humans. The significant importance of the higher overall antioxidant activity after the consumption of foods with a high flavonoid content (e.g., fruits, vegetables, tea, wine, or chocolate) might be explained by the change in the concentration of antioxidant metabolites in human plasma (for example, uric acid) [Lotito \& Frei, 2004a,b; 2006]. The addition of 'Red Delicious' apple extract to human plasma in vitro increased ferric reducing antioxidant power (FRAP). In this case, FRAP values of plasma increased from $454 \mu \mathrm{M}$ to $486 \mu \mathrm{M}(+7 \%)$ and up to $532 \mu \mathrm{M}(+17 \%)$, respectively, after the addition of 7 and $14 \mu \mathrm{g}$ of apple polyphenols to $1 \mathrm{~mL}$ of plasma [Lotito \& Frei, 2006]. Such an increase in plasma FRAP is comparable to the results reported after the consumption of other polyphenol-rich foods [Lotito \& Frei, 2006]. Further in vivo study of Wruss et al. [2015] has shown that the antioxidant activity of human plasma increased after apple consumption. The highest oxygen radical absorbance capacity (ORAC) of plasma was determined $1 \mathrm{~h}$ (120\% of change) and $6 \mathrm{~h}$ (120\% of change) post intake.

Moreover, the addition of apple polyphenols to plasma in vitro significantly increases its antioxidant resistance. Although apple polyphenols do not inhibit the peroxidation of ascorbate in plasma, the endogenous half-life of urate and $\alpha$-tocopherol and the delay in lipid oxidation were observed to be higher. Lotito \& Frei [2004a] demonstrated a high content of polyphenols in extracts from 'Red Delicious' apples, as reflected by a high radical scavenging activity in vitro. To prove this in vitro observation, in a further in vivo study by Lotito \& Frei [2004a], six volunteers consumed five apples per day to deliver a total of $1825 \mathrm{mg}$ of polyphenols. Plasma was collected $6 \mathrm{~h}$ after consumption, and antioxidant activity was measured. The results of an ex vivo study did not prove the in vitro measurements; no significant impact of apple polyphenols on plasma antioxidant status was found. Furthermore, the antioxidant activity of plasma measured by the FRAP method significantly increased $1 \mathrm{~h}$ after apple consumption, to $60 \mu \mathrm{M}$ of TE [Lotito \& Frei, 2004b]. In the next step, volunteers consumed $260 \mathrm{~g}$ of bagel, as a control without flavonoids and $750 \mathrm{~mL}$ of water; the amount was matched to the consumed amount of carbohydrates and weight of apples. Approx. $60 \mathrm{mg}$ of vitamin $\mathrm{C}$ was delivered with apples, which led to a slightly higher amount of ascorbic acid in plasma. The removal of ascorbate from plasma by ascorbate oxidase did not increase the antioxidant capacity. The results indicated that vitamin $\mathrm{C}$ from apples did not significantly modulate the antioxidant activity. The bagel consumption resulted in a decreased level of FRAP in plasma, which suggested the effect of food consumption per se [Lotito \& Frei, 2004a,b]. This hypothesis was also tested on the same six volunteers. They drank a solution of $64 \mathrm{~g}$ of fructose in $1000 \mathrm{~mL}$ of water, and the fructose amount was estimated according to the weight of five apples. Plasma activity, expressed as FRAP, significantly increased after about $1 \mathrm{~h}$, up to $40 \mu \mathrm{M}$, since fructose administration. Moreover, the changes in antioxidant activity depending on time were comparable to those observed after apple consumption. The concentration of uric acid in plasma significantly increased in every patient after fructose administration; the same was observed after apple consumption, while the level of ascorbate in plasma remained unchanged [Lotito \& Frei, 2004b]. This research is consistent with the findings reported by Wruss et al. [2015], who observed that an increase in the total phenolic content over time did not correlate with an observed, highly elevated antioxidant capacity in the blood plasma after apple juice consumption. In addition, they concluded that the antioxidant activity was rather due to a high fructose content of the apple juice.

ANTIOXIDANT ACTIVITY OF PHENOLIC
COMPOUNDS

The antioxidant activity of different food products has been broadly addressed in recent investigations [Shahidi \& Ambigaipalan, 2015]. For example, such products as coffee, tea, chocolate, wine, and beer possess high antioxidant activities that are linked to the high content of polyphenols. The total polyphenol content, including flavonoids, in fruits and juices is also correlated with the antioxidant activity of these products in vitro [Murillo et al., 2012].

Flavonoids are strong antioxidants in vitro, mainly because of their low redox potential and ability to donate electrons and hydrogen atoms; however, their activities vary For example, flavanols have a redox potential of $+0.53-$ $-0.57 \mathrm{~V}$. From a thermodynamic point of view, they can protect urates $(+0.59 \mathrm{~V})$ but not ascorbate $(+0.28 \mathrm{~V})$ against oxidation by peroxide radicals $(+1.06 \mathrm{~V})$. Therefore, they are more effective than ascorbate in the antioxidant protection of $\alpha$-tocopherol in a micellar solution [Frank et al., 2006]. However, high flavonoid contents are not always strictly correlated with strong antioxidant activity in the studied samples. For example, the highest antioxidant activity (ORAC assay) of blueberries was noted in their 'Northland' and 'North country' varieties, i.e., 6747 and $6265 \mu \mathrm{mol}$ $\mathrm{TE} / 100 \mathrm{~g}$ of fresh matter, respectively, whereas the highest total flavonoid content was determined in those of 'North country' and 'Blomidom' varieties [Wang et al., 2017]. A weak correlation was also demonstrated between antioxidant activity and total phenolic compounds for different varieties of apple [Jelodarian et al., 2012]. Despite the high antioxidant activity of flavonoids in vitro, their effectiveness in vivo is limited. In in vitro studies, the antioxidant activity of biologically active compounds of apples and their extracts were determined using the FRAP and ORAC methods [Lotito \& Frei, 2006]. Water extracts of the apple variety 'Red Delicious' contained $176 \mathrm{mg}$ of phenolic compounds per $100 \mathrm{~g}$ of apples. The FRAP and ORAC values were at 
1421 and $1508 \mu \mathrm{mol} \mathrm{TE} / 100 \mathrm{~g}$ apples, respectively. However, polyphenols contribute $14-18 \%$ of FRAP and ORAC values. This could mean that other biologically active compounds also make a high contribution to the overall antioxidant activity measured in vitro.

The high antioxidant activity of apples might also be related to their procyanidin contents. Procyanidins are found in fruit and cocoa products and are deemed good antioxidants due to their multiple hydroxyl groups [Hellstrom et al., 2009]. Their antioxidant potential depends on the chain length of oligomers and the type of oxygen they react with [Spranger et al., 2008; Zhou et al., 2014]. This also applies to apple procyanidins [Lu \& Foo, 2000]. Procyanidins and their monomer, possess comparable antioxidant efficiency against peroxide radicals, whereas procyanidins with different degrees of oligomerization different significantly in their lipid-protecting ability against oxidation induced by iron and ascorbate [Plumb et al., 1998]. Procyanidins are stronger antioxidants than more absorbable (-)-epicatechin and (+)-catechin.

As it was mentioned above, the effectiveness of flavonoids in vivo is limited; however, some studies reported an increase in the overall antioxidant activity in plasma. This observation leads to the general conclusion that flavonoids play an important role as antioxidants in plasma and tissues [Arts \& Hollman, 2005]. After the ingestion of food or a beverage, flavonoids in the ingested matrix must pass from the gut lumen into the circulatory system in order to be absorbed. Since in planta almost all flavonoids are in the form of glycosides, the attached sugar must be removed following consumption before absorption can take place [Williamson et al., 2018]. Some studies have pointed out that flavonoids are poorly absorbed and that their plasma concentrations are low even after flavonoid-rich food consumption [Lotito \& Frei, 2006].

\section{PHENOLIC COMPOUNDS - BIOAVAILABILITY AND ABSORPTION}

A crucial aspect of research dedicated to molecules with antioxidant properties is their bioavailability from food. The list of factors that influence the bioavailability of antioxidants is quite long [Porrini \& Riso, 2008]. They can be divided into four main categories: 1) related to the antioxidant (structure, molecular linkage, amount introduced, etc.); 2) related to food and its preparation (matrix characteristics, technological processing, presence of positive/negative effectors, etc.); 3) related to the host (disorders and/or pathologies, enzyme activity, gender, etc.); and 4) external (exposure to different environment and food availability). Also, the complex relationship between factors was discussed. In the mucosa of the intestine and liver, flavonoids are being modified via glucuronidation, methylation, and sulfating. Biotransformation influences their physical properties; therefore, they are more soluble in water and have better antioxidant properties. Some metabolites of phenolics have the same antioxidant activity as their precursors; however, in general, metabolites are weaker antioxidants because of the modifications of their catechol and phenol groups. Moreover, phenolics are degradable by digestive tract bacteria and their metabolites exhibit biolog- ical activity via an antioxidant or non-antioxidant mechanism [Minatel et al., 2017]. Phloretin was established as a urinary biomarker of apple intake by Saenger et al. [2017]. Phlorentin content determined in urine $12 \mathrm{~h}$ after apple consumption allows discriminating low- and high apple consumers. Therefore, the study of Yuste et al. [2018] proved that glucuronide derivatives of phloretin, catechol, and hydroxyphenyl- $\gamma$ -valerolactone, and also sulfate derivatives of dihydroxyphenylpropionic acid and (methyl) catechol are the main apple phenolic metabolites detected in human blood and plasma. In a further study, Yuste et al. [2019] specified that phlorentin glucuronide, and galactosides of cyanidin and peonidin were the intake markers of red-fleshed apples.

Quercetin is one of the most studied phenolic compounds because of its wide distribution in food and high antioxidant potential in vivo. Its main sources include onions, apples, tea, and wine. Quercetin occurs in a conjugated form as a quercetin glycoside. It is transferred to enterocytes via a sodiumdependent transporter of glucose 1. Some other studies pointed out that, before absorption in the intestine, enzymatic or bacterial deglycosylation takes place. Quercetin glycosides can persist in the bloodstream for more than $10 \mathrm{~h}$, which is longer than other flavonoids like anthocyanidins and flavanols. After the intake of foods rich in quercetin, its blood plasma level was at 0.7-7.6 $\mu \mathrm{M}$ [Lotito \& Frei, 2006]. In contrast to quercetin, flavanols are the main compounds of tea and chocolate, but are also found in apples (the amounts of $(+)$-catechin in apples and apple products are presented in Tables 1 and 2). Usually, flavanols occur in plants as aglycones and can be directly absorbed into the bloodstream. However, the concentration of free flavanols in the plasma is low were they are found in glucoronated and methylated forms. Anthocyanidins from berries and wines are absorbed intact, as glycosides. It was shown that their ethylated and glucuronated conjugates can be found in blood plasma in the nanomolar ranges [Porrini \& Riso, 2008]. Other important phenolics in apples, phloretin and phloridzin, were investigated in the plasma of rats by Crespy et al. [2001]. They showed that the highest concentration of phloretin, in both conjugated and unconjugated forms (conjugated forms of phloretin were dominant at $85-95 \%$ of the total amount), was found in plasma after $10 \mathrm{~h}$ and rapidly decreased after $24 \mathrm{~h}$. In turn, the research conducted by Rios et al. [2003] has shown that procyanidins are degraded by bacterial intestinal microflora to more absorbable phenolic acids with low molecular weights. While the bioavailability of quercetin, flavanols, and anthocyanidins in organisms is limited, the absorption of non-degradable procyanidins seems to be even lower, or almost null [Serra et al., 2010].

The absorption of flavonoids in humans is rather low in comparison to other antioxidants, such as vitamins $\mathrm{C}$ and E. Their maximum concentration in human plasma is observed between 1 and $3 \mathrm{~h}$ after flavonoid-rich food consumption. Levels of flavonols, flavanols, and flavanones are established at 0.006-7.6 $\mu \mathrm{M}$, while these of anthocyanidins are lower than $0.15 \mu \mathrm{M}$ [Hollman et al., 1997]. Moreover, the half-life of flavonoids in human plasma is short, reaching only a few hours. These limitations influence the higher activity of diet-derived flavonoids as antioxidants in vivo, in comparison to other active compounds present in higher amounts, 
TABLE 2. Phenolic compounds determined in products from apples according to apples' variety, country of origin and special pre-treatment.

\begin{tabular}{|c|c|c|c|c|c|}
\hline Material & $\begin{array}{l}\text { Country } \\
\text { of origin }\end{array}$ & $\begin{array}{c}\text { Apple } \\
\text { variety }\end{array}$ & Content of dominant phenolic compounds & Main remarks & Reference \\
\hline Juice & Germany & $\begin{array}{c}\text { 'Elstar Elshof' } \\
\text { (variety susceptible } \\
\text { to scab) } \\
\text { 'Rubinola' } \\
\text { (scab-resistant } \\
\text { variety) } \\
\end{array}$ & $\begin{array}{l}\text { procyanidin } B_{2}: \mathbf{7 4 . 6} \mathrm{mg} / \mathrm{L} \\
(-) \text {-epicatechin: } \mathbf{6 1 . 8} \mathrm{mg} / \mathrm{L} \\
\text { procyanidin } C_{1}: \mathbf{4 6 . 6} \mathrm{mg} / \mathrm{L} \\
\text { procyanidin } B_{2}: \mathbf{1 0 6 . 6} \mathrm{mg} / \mathrm{L} \\
(-) \text {-epicatechin: } \mathbf{8 9 . 9} \mathrm{mg} / \mathrm{L} \\
\text { procyanidin } C_{1}: \mathbf{5 3 . 3} \mathrm{mg} / \mathrm{L}\end{array}$ & $\begin{array}{l}\text { Higher content } \\
\text { of flavonoids } \\
\text { was determined } \\
\text { in varieties } \\
\text { resistant to scab }\end{array}$ & $\begin{array}{l}\text { Schempp } \\
\text { et al. [2016] }\end{array}$ \\
\hline Cloudy juice & & & $\begin{array}{l}\text { procyanidin } \mathrm{B}_{2}: \mathbf{1 6 9 . 5} \mathrm{mg} / \mathrm{L} \\
(-) \text {-epicatechin: } \mathbf{9 5 . 1} \mathrm{mg} / \mathrm{L}\end{array}$ & \multirow{3}{*}{$\begin{array}{l}\text { Addition } \\
\text { of ascorbic } \\
\text { acid preserved } \\
\text { the content } \\
\text { of flavonoids } \\
\text { in juice during } \\
\text { storage }\end{array}$} & \multirow{3}{*}{$\begin{array}{l}\text { Kolniak-Ostek } \\
\text { et al. [2013] }\end{array}$} \\
\hline $\begin{array}{l}\text { Cloudy juice after } \\
\text { 3-year storage } \\
\text { Cloudy juice with } \\
\text { ascorbic acid } \\
\text { (AA) addition }\end{array}$ & Poland & 'Shampion' & $\begin{array}{l}\text { procyanidin } \mathrm{B}_{2}: \mathbf{1 5 7 . 6} \mathrm{mg} / \mathrm{L} \\
\text { (-)-epicatechin: } \mathbf{9 5 . 1} \mathrm{mg} / \mathrm{L} \\
\text { procyanidin } \mathrm{B}_{2}: \mathbf{2 0 2 . 1} \mathrm{mg} / \mathrm{L} \\
\text { (-)-epicatechin: } \mathbf{7 3 . 7} \mathrm{mg} / \mathrm{L}\end{array}$ & & \\
\hline $\begin{array}{l}\text { Cloudy juice with } \\
\text { AA addition after } \\
\text { 3-year storage }\end{array}$ & & & $\begin{array}{l}\text { procyanidin } \mathrm{B}_{2}: \mathbf{1 6 5 . 9} \mathrm{mg} / \mathrm{L} \\
(-) \text {-epicatechin: } \mathbf{8 2 . 3} \mathrm{mg} / \mathrm{L}\end{array}$ & & \\
\hline $\begin{array}{l}\text { Cider after } \\
\text { maceration with } \\
\text { pulp and ethanol } \\
\text { fermentation }\end{array}$ & Turkey & 'Red Delicious' & $\begin{array}{c}\text { (+)-catechin: } \mathbf{1 . 4 6} \mathrm{mg} / \mathrm{L} \\
\text { (-)-epicatechin: } 3.33 \mathrm{mg} / \mathrm{L} \\
\text { caffeic acid: } \mathbf{0 . 7 5} \mathrm{mg} / \mathrm{L} \\
\text { chlorogenic acid: } \mathbf{1 6 . 5 0} \mathrm{mg} / \mathrm{L} \\
\text { p-coumaric acid: } \mathbf{0 . 0 4} \mathrm{mg} / \mathrm{L} \\
\text { (+)-catechin: } 2.13 \mathrm{mg} / \mathrm{L} \\
\text { (-)-epicatechin: } \mathbf{4 . 6 3} \mathrm{mg} / \mathrm{L} \\
\text { caffeic acid: } \mathbf{0 . 9 6} \mathrm{mg} / \mathrm{L} \\
\text { chlorogenic acid: } \mathbf{2 4 . 1 3} \mathrm{mg} / \mathrm{L} \\
\text { p-coumaric acid: } \mathbf{0 . 0 3} \mathrm{mg} / \mathrm{L}\end{array}$ & $\begin{array}{l}\text { Pulp maceration } \\
\text { increased } \\
\text { the content } \\
\text { of phenolic } \\
\text { compounds } \\
\text { in cider }\end{array}$ & $\begin{array}{l}\text { Budak } \\
\text { et al. }[2015]\end{array}$ \\
\hline $\begin{array}{l}\text { Vinegar (Heng } \\
\text { Shun) } \\
\text { Cider vinegar } \\
\text { (Heinz) } \\
\text { Cider vinegar } \\
\text { (Xin He) }\end{array}$ & China & $\begin{array}{l}\text { no information, } \\
\text { commercial } \\
\text { samples }\end{array}$ & $\begin{array}{c}\text { protocatechuic acid: } \mathbf{0 . 8 2} \mu \mathrm{g} / \mathrm{mL} \\
\text { chlorogenic acid: } \mathbf{1 0 . 9 1} \mu \mathrm{g} / \mathrm{mL} \\
\text { p-coumaric acid: } \mathbf{0 . 1 7} \mu \mathrm{g} / \mathrm{mL} \\
\text { protocatechuic acid: } \mathbf{1 . 5 4} \mu \mathrm{g} / \mathrm{mL} \\
\text { chlorogenic acid: } \mathbf{2 . 9 9} \mu \mathrm{g} / \mathrm{mL} \\
\text { protocatechuic acid: } \mathbf{1 . 0 0} \mu \mathrm{g} / \mathrm{mL} \\
\text { chlorogenic acid: } \mathbf{0 . 2 3} \mu \mathrm{g} / \mathrm{mL}\end{array}$ & $\begin{array}{l}\text { The content } \\
\text { of phenolic } \\
\text { compounds } \\
\text { differed among } \\
\text { vinegars from } \\
\text { various producers }\end{array}$ & $\begin{array}{l}\text { Liu } \\
\text { et al. [2019] }\end{array}$ \\
\hline Vinegar & Turkey & 'Malus domesticus' & $\begin{array}{c}\text { gallic acid: } \mathbf{0 . 8} \mathrm{mg} / 100 \mathrm{~mL} \\
\text { p-hydroxybenzoic acid: } \mathbf{0 . 2} \mathrm{mg} / 100 \mathrm{~mL} \\
(+) \text {-catechin: } \mathbf{2 . 4} \mathrm{mg} / 100 \mathrm{~mL} \\
\text { syringic acid: } \mathbf{0 . 1 2} \mathrm{mg} / 100 \mathrm{~mL} \\
\text { caffeic acid: } \mathbf{0 . 4} \mathrm{mg} / 100 \mathrm{~mL} \\
\text { p-coumaric acid: } \mathbf{0 . 0 8} \mathrm{mg} / 100 \mathrm{~mL}\end{array}$ & $\begin{array}{l}\text { Significant } \\
\text { changes appeared } \\
\text { in phenolic } \\
\text { compounds during } \\
\text { vinegar making }\end{array}$ & $\begin{array}{l}\text { Bakir } \\
\text { et al. }[2016]\end{array}$ \\
\hline $\begin{array}{l}\text { Pomace after } \\
\text { microwave } \\
\text { blanching; } \\
50^{\circ} \mathrm{C}, 5 \mathrm{~min}\end{array}$ & Cameroon & 'Malus sylvestris' & $\begin{array}{l}\text { (-)-epicatechin, caffeic acid and quercetin } \\
\text { Total amount: } \mathbf{1 4 1 . 3 0} \mathrm{mg} / 100 \mathrm{~g} \text { DW } \\
\text { Gallic acid, (-)-epicatechin, caffeic } \\
\text { acid, } p \text {-coumaric acid, ferulic acid, } \\
\text { rosmarinic acid, quercetin. } \\
\text { Total amount: } \mathbf{9 3 . 1 3} \mathrm{mg} / 100 \mathrm{~g} \text { DW }\end{array}$ & $\begin{array}{l}\text { The content } \\
\text { of phenolic } \\
\text { compounds } \\
\text { increased after } \\
\text { blanching }\end{array}$ & $\begin{array}{l}\text { Dibanda } \\
\text { et al. }[2020]\end{array}$ \\
\hline
\end{tabular}

e.g., $30-150 \mu \mathrm{M}$ of vitamin $\mathrm{C}, 160-450 \mu \mathrm{M}$ of urinate, or 15-40 $\mu \mathrm{M}$ of vitamin E. Long-term consumption of flavonoid-rich food does not lead to the accumulation of their high amounts in plasma. Concentrations of quercetin in human plasma are lower than $1 \mu \mathrm{M}$ [Loito \& Frei, 2006]. Data about the concentration of flavonoids in human tissues are not available, but it is unlikely that flavonoids have a significant impact on the antioxidant activity in cells, where ascorbate and reduced glutathione can be found in $\mathrm{mM}$ concentrations [Loito \& Frei, 2006]. Poorly absorbed phenolic compounds are metabolized in intestines and liver. Moreover, they are good substrates and indicators of phase II enzymes [Williamson et al., 1996]. This suggests that they are recognized by organisms as xenobiotics, potentially toxic compounds, because of their polyhydroxy structure and strong redox potential [Dunnick \& Hailey, 1992]. Therefore, by inducing the detoxification of enzymes, flavonoids protect the organism against mutagenic and carcinogenic factors, thus preventing cancer development [Knekt et al., 2002]. Probably, the absorbed flavonoids (in low concentrations) and their metabolites exert other biological activities, including e.g., changing cell signaling and gene expression, which contributes to the health benefits. Hence, flavonoids after intensive metabolic transformations and chemical forms of flavonoids present in fruits and vegetables (mainly glycosides, except for flavanols in aglycon forms), differ from the metabolites formed in vivo. 


\section{FACTORS INFLUENCING THE CONTENT OF PHENOLIC COMPOUNDS IN APPLES}

There are a lot of factors influencing the phenolic content in apples. In the West Himalayan apple varieties, the phenolic content was significantly differentiated among cultivars and locations [Bahukhandi et al., 2018]. It was also confirmed that the variety and maturity of apples significantly affected their chemical composition, content of phenolics, and antioxidant activity [Oszmiański et al., 2008]. Oszmiański et al. [2008] compared 120 apple varieties and found they were highly diversified in terms of pehnolics content. According to this research, the highest phenolic content was found in apples of 'Ozark Gold' variety ( 2116.03 mg/kg), whereas the lowest one in these of 'Ligol' variety $(\sim 814.17 \mathrm{mg} / \mathrm{kg})$. The quality and quantity of phenolics in apples directly influences their antioxidant activity [Wojdyło et al., 2008]. Orchard cultivation system has an impact on the chemical composition of apples as well. Apples from organic farming have a higher content of phenolics in comparison to those from conventional cultivation [Wojdyło et al., 2010]. Sut et al. [2019] noted that the content of phloretin 2-O-xyloglucoside and quercetin 3-O-arabinoside was significantly higher in ancient apple varieties ('Friuli Venezia Giulia', northern Italy) than in the commercial ones (e.g., 'Golden Delicious', 'Red Delicious', 'Granny Smith', and 'Royal Gala'). Also, ancient Croatian apple varieties were observed to be an important source of phenolics, especially proanthocyanidins, phenolic acids, and dihydrochalcones, compared to the commercial ones [Jakobek et al., 2013]. Also, Kschonsek et al. [2018] noticed the significant difference in phenolics content between old (29 mg/ $100 \mathrm{~g})$ and new (13 mg/ $100 \mathrm{~g})$ cultivars of apples from Germany. It might be said that even the ancient cultivars can be a good source of bioactive compounds in the formulation of novel products. However, the results are not unambiguous in comparison to other research data. For example, the peel, pomace, and juice made of the old Spanish cultivar 'Verde Doncella' had lower contents of flavanols and quercetin derivatives compared to 'Red Delicious' cultivar. However, this study pointed out that 'Verde Doncella' had a higher content of $p$-coumaric acid and procyanidin $\mathrm{B}_{2}$ in the peel [Krawitzky et al., 2014]. Interesting results were described by Skłodowska et al. [2018], who observed that apple leaves might be a rich source of bioactive compounds due to the variety and geographical origin, which significantly differentiated the apple leaf phenolics. The methods and conditions of apple processing also have a major impact on polyphenols.

\section{FACTORS INFLUENCING THE CONTENT OF PHENOLIC COMPOUNDS IN APPLE PRODUCTS}

In Poland, clarified beverages and wines are the most popular products made from apple juice concentrate. This type of manufacturing leads to large differences in the chemical composition between the raw material and the final product, such as an almost total lack of pectin and vitamin C, and 90\% loss of phenolics. The lowest content of valuable procyanidin is found in apple juice. Procyanidins bind to the cell walls of apples and are removed during the clarification process of juice. This leads to a significant decrease in the polyphenols in juices [Kolniak-Ostek et al., 2013]. Oszmiański \& Wojdyło [2009] noted a 6-fold lower antioxidant activity of apple juice compared to blackcurrant juice. Cloudy and puree juices are good alternatives to clarified apple juices. The content of phenolic compounds depends on the apple variety and type of manufactured juice. Clarified juice made of 'Idared' apples contained only $250.1 \mathrm{mg} / \mathrm{L}$ of phenolics, whereas the content in cloudy juice made from 'Szampion' was 5-fold higher reaching $1044.4 \mathrm{mg} / \mathrm{L}$ of juice [Oszmiański et al., 2007]. Cloudy juice made of 'Szampion' apples had up to $31 \%$ higher antioxidant potential, measured by the DPPH method, and that made of 'Idared' apples had about $45 \%$ higher antioxidant potential than the respective clarified juices [Oszmiański et al., 2007]. In other research, cloudy juices produced without the enzymatic treatment, clarification, or filtration contained more biologically active compounds [Oszmiański \& Wojdyło, 2009]. The juice clarification process removes brow products of phenolic compounds oxidation. Omitting this step in cloudy juice manufacture leads to their unattractive brown color. Cloudy juices should be produced from high-quality, fresh, and matured apples. Their cloudiness can range from $15 \%$ (var. 'Elstar') to 47\% (var. 'Gostar') [Wojdyło et al., 2008]. Schempp et al. [2016] noted that 'Elstar' variety was a rich source of flavanols, e.g., (-)-epicatechin, and their oligomers, e.g., procyanidin $\mathrm{B}_{2}$ and $\mathrm{C}_{1}$, with their content approximating $240.0 \mathrm{mg} / \mathrm{L}$. Considering the oxidation and browning of juices, they should be manufactured in an inert gas environment, after ascorbic acid addition to the pulp. The quality of cloudy juices can be improved by employing decanting instead of pressing. Juice production using decanters takes only a few seconds, which inhibits the oxidation of crushed fruits. The addition of ascorbic acid or rhubarb to apple pulp during fruit crushing reduces the effects of oxidation processes, including color change. The addition of ascorbic acid proved necessary in all types of juices except for those made of var. 'Szampion' apples. Juices with ascorbic acid contain significantly more phenolic compounds (approx. 1.2-fold higher) and have higher antioxidant activity (3.5-fold higher) compared to juices without its addition [Kolniak-Ostek et al., 2013]. Promising results in terms of decreasing the browning of juices were achieved by using high-pressure carbon dioxide treatment [Murtaza et al., 2020]. This processing of juices also increased (-)-epicatechin and (+)-catechin concentrations; however, more studies need to be done to establish the appropriate temperature and pressure conditions to achieve the highest content of phenolics. In another study, an attempt to increase the content of phenolic compounds and antioxidant activity in apple juices and beverages by the enzymatic treatment of apple pulp and the addition of apple leaves proved successful [Zielinski et al., 2014]. The phenolic compound contents increased by 2 to 5 times, whereas the antioxidant potential by about 1.29 times. Moreover, the addition of apple puree produced from different enzymatic formulations increased the phenolic content in the studied juices from $441 \mathrm{mg} / \mathrm{L}$ to $612 \mathrm{mg} / \mathrm{L}$, and antioxidant activity by $5-21 \%$ [Zielinski et al., 2014]. The obtained data show that enriching natural cloudy juices with ascorbic acid, apple pulp or leaves is useful. If enriched with this technology, juices can be an 
attractive product, with antioxidants that will have a beneficial influence on human health. Oszmiański et al. [2008] demonstrated a high content of polyphenolic compounds and antioxidant activity in juices made of 'Idared' apples. Furthermore, the addition of blackcurrants not only enriched apple juice with phenolic compounds and improved its color, but also protected it from enzymatic oxidation. Ascorbic acid from blackcurrants, used in this reaction, also effectively protected the polyphenols of 'Idared' apples from oxidation. Antioxidant activity is measured as the ability to scavenge DPPH radicals; therefore, the antioxidant activity of blackcurrant juice was about 40-fold higher than that of apple juice. The addition of $20 \%$ blackcurrant juice to apple juice increased the antioxidant activity about 8-fold in comparison to apple juice without any additives [Oszmiański et al., 2008]. However, Średnicka-Tober et al. [2017] demonstrated that the addition of chokeberry juice to apple juice led to a decrease in quercetin and kaempferol contents. Whereas green tea extract addition resulted in a significant enrichment of apple juice with phenolic acids ( $\sim 2$ - times) and flavonoids ( $\sim 10$ - times $)$, with molecules characteristic for tea: $(+)$-catechin, (-)-epicatechin, (-)-epigallocatechin, and (-)-epigallocatechin 3-O-gallate. Bat et al. [2018] successfully used phytochemicals as markers to prove the origin and variety of apple juices. Moreover, Adamenko et al. [2019] established a new product, i.e., fermented apple beverage with Cornelian cherry addition (10\%) having a strong antioxidant properties (ABTS, DPPH, and FRAP tests) and enriched with phenolic compounds and iridoids. This treatment caused the highest content of 5-O-caffeoylquinic acid (from 70.0 to $96.8 \mathrm{mg} / \mathrm{L}$ ). In turn, Verdu et al. [2014] presented that the apple progeny significantly influenced the phenolic compounds content of another type of apple beverage, namely cider. The content of 12 phenolics varied in apples as a genetic effect and between harvest years.

Kahle et al. [2005] pointed out that the phenolic compounds content was significantly different in juices made from dessert or cider apples. Moreover, there was a difference in phenolic contents between apple cultivars, while freshly squeezed juices were richer in phenolic compounds than commercially available juices. The influence of storage on phenolic stability in apple juices was also studied by Maragó et al. [2015]. They demonstrated that the contents of total phenolics and flavanols were almost 5-fold and 8-fold higher, respectively, in 'Panaia-red' juice than in juice made of 'Golden Delicious' apples. Higher stability of phenolics was achieved in 'Panaia-red' juice. Pavun et al. [2018] highlighted that the use of fruit nectar definitely lowered the phenolic content in commercial juices, which was ultimately correlated with their antioxidant activity. It was also demonstrated that not pasteurization but pre-pasteurization had a significantly stronger impact on phenolics content during processing of not from concentrate (NFC) juices [Tian et al., 2018].

Another important aspect affecting contents of antioxidants is the technological preparation of raw fruits. The microwave-treatment of apple peels [Dibanda et al., 2020] and their storage method affected phenolics content and antioxidant activity [Santarelli et al., 2020]. According to Santarelli et al. [2020], there is a difference between the response of tissues of organicaly and conventionally farmed apples to freezing. The antioxidant activity of organic apples after freezing was reduced by only $13 \%$, whereas in the conventional ones a decrease of up to $25 \%$ was noted. This was related to the higher resistance of organic apple tissue to thermal stress, which caused a decrease in free and conjugated phenolics related to antioxidant activity. Fernández-Jalao et al. [2019] increased extractability of flavonoids from apple pulp by up to $54 \%$ using high-pressure processing at $600 \mathrm{MPa}$. In another study, Ferrentino et al. [2018] successfully used supercritical fluid extraction to improve the recovery of extracted phenolics from apple pomace. The mechanism of these two methods might be related to the flavonoid compounds from cell walls being trapped in an insoluble matrix.

Also, the consumption of dried apples is quite popular among consumers nowadays. It is known that food product stability over storage period is an important aspect to be considered during its production process. In this context, the addition of a green tea extract to dried apples might be a perfect solution, providing a new type of product that would combine the preservation of apples and an increased phenolic content in the final product [Corey et al., 2011]. Pająk et al. [2017] proposed biofilms made of white or green tea extracts to prolong the freshness of sliced apples. The proposed application of white tea allowed them to obtain a stored product with a similarly high content of total phenolics to that in the fresh material. Tappi et al. [2018] used cold atmospheric plasma to study the effect of phenolic behavior in fresh-sliced apples. They noticed that phenolic content significantly decreased in slices after $2 \mathrm{~h}(1.774 \mathrm{mM} / \mathrm{kg}$ fresh weight); however, it was not significantly lower after half an hour (from 2.142 to $2.092774 \mathrm{mM} / \mathrm{kg}$ fresh weight). The high content of phenolic compounds and health-promoting properties of food products play an important role in consumer acceptance. From the sensory point of view, in the study of Wang et al. [2019a], the most preferred by the panelists were the dried apple slices pretreated with steam blanching and osmotic dehydration of the apple slices. Freeze-dried apple powders were also found to be good sources of antioxidants [Raudone et al., 2016], like chlorogenic acid and procyanidin $C_{1}$ which were responsible for their high antioxidant activity.

Apples are eagerly consumed mostly because of their pleasant taste and the fact that they are widely available worldwide. FAO statistics reported that, in 2016, the global production of apples exceeded 80 million tons, and over 3 million were converted into juice [Matsuoka, 2019]. According to these statistics, a large amount of waste is simultaneously produced. Therefore, growing attention has been paid to the reuse or limitation of the amount of waste produced. The benefits of apple pomace consumption were described in a publication prepared by Skinner et al. [2018]. The positive antioxidant effect on human health might be related to the phenolics in this apple waste. Therefore, quercetin $(5.72 \mu \mathrm{g} / \mathrm{kg})$, phloretin $(2.01 \mu \mathrm{g} / \mathrm{kg})$, and phloridzin $(1.23 \mu \mathrm{g} /$ $\mathrm{kg}$ ) were determined to be the main phenolics in apple pomace [Rana et al., 2015]. Apple peel is also a rich source of bioactive compounds [Raudone et al., 2017]. Its main flavonoids are (-)-epicatechin and quercetin, at 0.28 and $0.19 \mathrm{mg} / \mathrm{g}$, respectively [Bhagwat et al., 2011]. This is in agreement 
with Escarpa \& González [2001], who found high amounts of phenolic compounds (in the order: rutin, chlorogenic acid, and (+)-catechin) in "Golden" and "Reinette" apples (both peel and pulp). A possible innovation is the use of apple peels after microwaving, which is a good method for releasing phenolic compounds bound in the cell wall [Dibanda et al., 2020]. Furthermore, apple peels can be a good component to formulate functional foods, because of the high total phenolic content (1.1 g GAE/g of dry weight). Du et al. [2020] proposed "cold-pressing technology" as an effective method for peeling and deseeding apple fruits, with a positive effect on phenolic compounds retention in pomace. A 3- to 18-fold higher content of gallic and vanillic acids, (-)-epicatechin 3-O-gallate, and phloridzin was detected in apple pulp than in juice, cider, and/or vinegar. Xu et al. [2016] pointed out that seeds could also be a rich source of phenolic compounds. However, the content of phenolics differs in seeds from different apple cultivars. The dominant phenolics determined in seeds were phloridzin $>$ hyperin $>$ chlorogenic acid. Other examples of apple products and the main conclusions about phenolics variation during apple processing are summarized in Table 2.

\section{METHODS OF PHENOLICS DETERMINATION AND ANTIOXIDANT ACTIVITY MEASUREMENT IN APPLES}

A broad review of phenolic compounds' determination was prepared by Naczk \& Shahidi [2004]. They gathered the main existing knowledge about phenolic compound extraction and analysis of their profile using spectrophotometric and chromatographic methods; however, since then, some new insights have been presented in this respect. The Folin-Ciocalteu's reagent is still commonly used to spectrophotometrically characterize the total content of phenolic compounds in apples and their products [Azlan et al., 2018; Bakir et al., 2016; Dhyani et al., 2018; Xu et al. 2016 ]. Total phenolic content is one of the most frequently analyzed factors, even after it was shown that the spectrophotometric method can lead to inaccurate results because of the strong interference of sugars and proteins in the assay results [Escarpa \& Gonzalez, 2001]. In this context, HPLC-UV-VIS was used to determine the phenolic compound profiles in apple samples, preceded by an appropriate extraction procedure. Solvent extraction, sample fragmentation and its pretreatment, and compound-of-interest isolation are also important steps [Starowicz, 2019]. For example, Stan et al. [2017] proposed conventional extraction as a more efficient method to extract phenolics from dried apples than microwave- or ultrasound-assisted extraction. However, they noted that the content of compounds extracted can be different upon using different extraction procedures. Chlorogenic acid, (+)-catechin, and quercetin contents were higher after conventional than microwave-assisted extraction. The microstructure analysis conducted by Wang et al. [2019b] revealed that ultrasound treatment released phytochemicals from fruit cell walls, proving to represent a more efficient technique to increase phenolic compounds extractability. An interesting procedure was presented by Loncarić et al. [2020], who extracted flavonoids from apple peels using micro-matrix solid-phase dispersion (micro-MSPD) with sea sand and a solvent mixture of methanol:water:formic acid. Also, different instrumentation is used to increase the efficiency of compound determination. Both qualitative and quantitative methods are in matter of interest, and can be used with internal/external standards to determine phenolic compounds content. The HPLC with a diode array detector (DAD) is the most common method applied for phenolic compound determination in apples [Duda-Chodak et al., 2010]. However, its modifications were proposed in further studies. Gomes et al. [2016] used the electrochemical properties of flavonoids to measure their content in fruit powders by RP-HPLC-EC. This method was appropriate to determine low content of selected polyphenols in either fresh or dried samples. The LC-MS/MS was also adapted to phenolic compound determination in samples of apples because of its low sensitivity and good repeatability [Loncarić et al., 2020]. In the study of Jakobek et al. [2013], two different detectors were used to determine contents of specific phenolic compounds in apples, i.e., UV-Vis and MS/MS. Moreover, using various HPLC columns and conditions in the inter-laboratory study, Hollands et al. [2017] developed, validated, and assessed analytical method for the separation, identification and quantification of procyanidins in an apple extract. Additionally, many researchers have tried to establish a relationship between bioactive compounds and antioxidant activity, to determine which phenolic compound has the greatest influence on antioxidant activity.

There are several mechanisms of the antioxidant action of phenolic compounds and therefore different methods must be used to determine their antioxidant activity. Alam et al. [2013] found that the most frequent methods used to determine antioxidant activity in vitro in plant material are: $\alpha, \alpha$-diphenyl- $\beta$-picrylhydrazyl (DPPH) radical scavenging assay, hydroxyl radical scavenging assay, and superoxide radical scavenging activity determination. According to these authors, the in vivo methods frequently used to determine antioxidant activity included lipid peroxidation assay (LPO) in tissues and determination of superoxide dismutase (SOD) and catalase (CAT) activities in erythrocytes of experimental animals. The antioxidant activity is often measured by using a few methods. The $\mathrm{DPPH}^{\cdot}$ and $\mathrm{ABTS}^{\cdot+}$ scavenging activities of apple extracts were measured by Duda-Chodak et al. [2010]. A significant difference was found between the analyzed ABTS ${ }^{*+}$ scavenging activities of apple extracts, whereas no significant differences were noted in the DPPH method. Also, the FRAP method is usually introduced to evaluate antioxidant capacity. Pająk et al. [2017] found a high correlation between the antioxidant activities measured by FRAP, DPPH, and ABTS assays, and total phenolic content (with correlation coefficients of $0.914,0.950$, and 0.965 , respectively). Furthermore, ethanol, water, and methanol are the solvents most commonly used to extract phenolic compounds before antioxidant activity determination usually conducted with spectrophotometric methods using cuvettes. As an innovation, Horszwald \& Andlauer [2011] proposed 96-well plates (measurement done on a microplate reader) instead of cuvettes. The main advantages of this method are the low amounts of chemicals and extracts needed, and the very good repeat- 
ability of the results obtained. Gökmen et al. [2009] presented a novel approach, "QUENCHER," to the analysis of antioxidant activity. A direct QUENCHER procedure allows measuring the antioxidant activity in the samples in which "a great part of antioxidants is bound to insoluble matrices" [Gökmen et al., 2009]. An interesting method was presented by Raudone et al. [2017], in which a combination of HPLC-DAD and FRAP assay was applied to measure the flavonoid content and antioxidant activity in apples and apple peels. Based on the HPLC-DAD-FRAP post-column analysis, it was established that among 12 flavanol compounds, flavanols and phenolic acids exhibited antioxidant activity, whereas no ferric ion reducing activity was observed for phloridzin. Therefore, it was observed that phloridzin cannot be used as a reference compound in antioxidant activity determination.

\section{CONCLUSIONS}

Apples are an important source of phenolics in the human diet, and their consumption has been implicated in the prevention of degenerative diseases. The polyphenols that can be found in apple peel and pulp are flavonols (mainly quercetin and its glycosides), flavanols ((-)-epicatechin and (+)-catechin), procyanidins, anthocyanidins, and dihydrochalcones (phloridzin and its derivatives). Their content was strictly related to the geographical origin, variety, and processing techniques of the apple products. Information about cultivar-typical apple polyphenol content and profile is important for bioactivity studies and, consequently, essential for the development of consumer-relevant products with particular nutritional functionalities. As to what the future holds, much work should be put into determining the bioavailability, transport, and bioactivity of dietary flavonoids. Moreover, a strong emphasis should be put in further studies on the reuse of apple by-products, e.g., peels and seeds, as novel food components.

\section{ORCID IDs}

M. Starowicz https://orcid.org/0000-0001-6053-2250; M.K. Piskuła https://orcid.org/0000-0001-7953-0909; H. Zieliński https://orcid.org/0000-0002-4333-6677.

\section{REFERENCES}

1. Adamenko, K., Kawa-Rygielska, J., Kucharska, A.Z., Piórecki, N. (2019). Fruit low-alcoholic beverages with high contents of iridoids and phenolics from apple and Cornelian cherry (Cornus mas L.) fermented with Saccharomyces bayanus. Polish Journal of Food and Nutrition Sciences, 69(3), 307-317.

https://doi.org/10.31883/pjfns/111405

2. Alam, Md.N., Bristi, N.J., Rafiquzzaman, Md. (2013). Review on in vivo and in vitro methods evaluation of antioxidant activity. Saudi Pharmaceutical Journal, 21 (2), 143-152.

https://doi.org/10.1016/j.jsps.2012.05.002

3. Arts, I.C., Hollman, P.C. (2005). Polyphenols and disease risk in epidemiologic studies. American Journal of Clinical Nutrition, 81(1), S317-S325.

https://doi.org/10.1093/ajcn/81.1.317S
4. Azlan, A., Kok, Y.W., Khoo, H.E. (2018). Antioxidants content and activity of polyphenol-rich mixtures. Journal of Engineering and Applied Sciences, 13(9), SI, 6973-6979.

http://doi.org/10.36478/jeasci.2018.6973.6979

5. Bahukhandi, A., Dhyani, P., Bhatt, I.D., Rawal, R.S. (2018). Variation in polyphenolics and antioxidant activity of traditional apple cultivars from West Himalaya, Uttarakhand. Horticultural Plant Journal, 4(4), 151-157.

https://doi.org/10.1016/j.hpj.2018.05.001

6. Bakir, S., Toydemir, G., Boyacioglu, D., Beekwilder, J., Capanoglu, E. (2016). Fruit antioxidants during vinegar processing: changes in content and in vitro bio-accessibility. International of Molecular Sciences, 17(10), art. no. 1658. https://doi.org/10.3390/ijms17101658

7. Bat, K.B., Vodopivec, B.M., Eler, K., Ogrinc, N., Mulič, I., Masuero, D., Vrhovšek, U. (2018). Primary and secondary metabolites as a tool for differentiation of apple juice according to cultivar and geographical origin. LWT - Food Science and Technology, 90, 238-245. https://doi.org/10.1016/j.Iwt.2017.12.026

8. Bhagwat, S.B., Haytowitz, D.B., Holden, J.M. (2011). USDA database for the flavonoid content of selected foods. Release 3.1. Available on-line at [https://www.ars.usda.gov/ARSUserFiles/80400525/ Data/Flav/Flav_R03-1.pdf]. Accessed 21 Janaury 2020.

9. Bosetti, C., Spertini, L., Parpinel, M., Gnagnarella, P., Lagiou, P., Negri, E., Franceschi, S. (2005). Flavonoids and breast cancer risk in Italy. Cancer Epidemiological Biomarkers Prevention, 14, 805-808. https://doi.org/10.1158/1055-9965.EPI-04-0838

10. Budak, N.H., Ozçelik, F., Güzel-Seydim, Z.B. (2015). Antioxidant activity and phenolic content of apple cider. Turkish Journal of Agriculture - Food Science and Technology, 3(6), 356-360. https://doi.org/10.24925/turjaf.v3i6.356-360.265

11. Calderón-Oliver, M, Ponce-Alquicira, E. (2018). Fruits: a source of polyphenols and health benefits. Eds. A.M. Grumezescu, A.M. Holban, In Handbook of Food Bioengineering, Natural and Artificial Flavoring Agents and Food Dyes, Academic Press, London, United Kingdom, pp. 189-228.

https://doi.org/10.1016/B978-0-12-811518-3.00007-7

12. Corey, M.E., Kerr, W.L., Mulligan, J.H., Lavelli, V. (2011). Phytochemical stability in dried apple and green tea functional products as related to moisture properties. LWT - Food Science and Technology, 44(1), 67-74. https://doi.org/10.1016/j.Iwt.2010.07.005

13. Crespy, V., Aprikian, O., Morand, Ch., Besson, C., Manach, C., Demigné, Ch., Rémésy, Ch. (2001). Bioavailability of phloretin and phloridzin in rats. The Journal of Nutrition, 131(12), 3227-3230. https://doi.org/10.1093/jn/131.12.3227

14. Del Bo, C., Bernardi, S., Marino, M., Porrini, M., Tucci, M., Guglielmetti, S., Cherubini, A., Carrieri, B., Kirkup, B., Kroon, P., Zamora-Ros, R., Liberona, N.H., Andres-Lacueva, C., Riso, P. (2019). Systematic review on polyphenol intake and health outcomes: is there sufficient evidence to define a health-promoting polyphenol-rich dietary pattern? Nutrients, 11 (6), art. no. e1355. https://doi.org/10.3390/nu11061355

15. Dhyani, P., Bahukhandi, A., Rawat, S., Bhatt, I.D., Rawal, R.S. (2018). Diveristy of bioactive compounds and antioxidant activity in Delicious group of apple in Western Himalaya. Journal of Food Science and Technology - Mysore, 55(7), 2587-2599. https://doi.org/10.1007/s13197-018-3179-x 
16. Dibanda, R.F., Akdowa, E.P., Rani, P.A. Tongwa, Q.M., Mbofung C.M.F. (2020). Effect of microwave blanching on antioxidant activity, phenolic compounds and browning behaviour of some fruit peelings. Food Chemistry, 302, art. no. 125308. https://doi.org/10.1016/j.foodchem.2019.125308

17. Du, G.R., Zhu, Y.Y., Wang, X.Y., Zhang, J., Tian, C.R.., Liu, L., Meng, Y.H., Guo, Y.R. (2019). Phenolic composition of apple products and by-products based on cold-pressing technology. Journal of Food Science and Technology - Mysore, 56(3), 1389-1397. https://doi.org/10.1007/s13197-019-03614-y

18. Duda-Chodak, A., Tarko, T., Satora, P., Sroka, P., Tuszyński, T. (2010). The profile of polyphenols and antioxidant properties of selected apple cultivars grown in Poland. Journal of Fruit an Ornamental Plant Research, 18(2), 39-50.

19. Dunnick, J.K., Hailey, J.R. (1992). Toxicity and carcinogenicity studies of quercetin, a natural component of foods. Toxicological Sciences, 19(3), 423-431. https://doi.org/10.1093/toxsci/19.3.423

20. Escarpa, A., González, M.C. (2001). Approach to content of total extractable phenolic compounds from different food samples by comparison of chromatographic and spectrophotometric methods. Analytica Chimica Acta, 427(1), 119-127. https://doi.org/10.1016/S0003-2670(00)01188-0

21. Fernández-Jalao, I., Sánchez-Moreno, C., De Ancos, B. (2019). Effect of high-pressure processing on flavonoids, hydrocinnamic acids, hydrochalcones and antioxidant activity of apple 'Golden Delicious' from different geographical origin. Innovative Food Science \& Emerging Technologies, 51, SI, 20-31.

https://doi.org/10.1016/j.ifset.2018.06.002

22. Ferrentino, G., Morozova, K., Mosibo, O.K., Ramezani, M., Scampicchio, M. (2018). Biorecovery of antioxidants from apple pomace by supercritical fluid extraction. Journal of Cleaner Production, 186, 253-261.

https://doi.org/10.1016/j.jclepro.2018.03.165

23. Francini, A., Sebastiani, L. (2013). Phenolic compounds in apple (Malus $x$ domestica Borkh.): compounds characterization and stability during postharvest and after processing. Antioxidants, 2(3), 181-193.

https://doi.org/10.3390/antiox2030181

24. Frank, J., Budek, A., Lundh, T., Parker, R.S., Swanson, J.E., Lourenço, C.F., Gago, B., Laranjinha, J., Vessby, B., Kamal-Eldin, A. (2006). Dietary flavonoids with a catechol structure increase $\alpha$-tocopherol in rats and protect the vitamin from oxidation in $v i$ tro. Journal of Lipid Research, 47(12), 2718-2725.

https://doi.org/10.1194/jlr.M600291-JLR200

25. George, V.C., Rupasinghe, H.P.V. (2017). Apple flavonoids suppress carcinogen-induced DNA damage in normal human bronchial epithelial cells. Oxidative Medicine and Cellular Longevity, 2017, art. no. 1767198 .

https://doi.org/10.1155/2017/1767198

26. Giacalone, M., Di Sacco, F., Traupe, I., Pagnucci, N., Forfori, F., Giunta, F. (2015). Blueberry polyphenols and neuroprotection. Eds. R.R. Watson, V.R. Preedy, In Bioactive Nutraceuticals and Dietary Supplements in Neurological and Brain Disease, Prevention and Therapy, 1, Academic Press, Cambridge, USA, pp. 17-28. https://doi.org/10.1016/B978-0-12-411462-3.00002-3

27. Gökmen, V., Serpen, A., Fogliano, V. (2009). Direct measurement of the total antioxidant capacity of foods: the 'QUENCHER' approach. Trends in Food Science \& Technology, 20(6-7), 278-288. https://doi.org/10.1016/j.tifs.2009.03.010
28. Gomes, S.M.C., Ghica, M.-CE., Rodrigues, I.A., de Souza Gil, E., Oliveira-Brett, A.M. (2016). Flavonoids electrochemical detection in fruit extracts and total antioxidant capacity evaluation. Talanta, 154, 284-291. https://doi.org/10.1016/j.talanta.2016.03.083

29. Guo, X.F., Ruan, Y., Li, Z.H., Li, D. (2019). Flavonoid subclasses and type 2 diabetes mellitus risk: a meta-analysis of prospective cohort studies. Critical Reviews in Food Science and Nutrition, 59(17), 2850-2862. https://doi.org/10.1080/10408398.2018.1476964

30. Habanova, M., Saraiva, J.A., Holovicova, M., Moreira, S.A., Fidalgo, L.G., Haban, M., Gazo, J., Schwarzova, M., Chlebo, P., Bronkowska, M. (2019). Effect of berries/ apple mixed juice consumption on the positive modulation of human lipid profile. Journal of Functional Foods, 60, art. no. 103417. https://doi.org/10.1016/j.jff.2019.103417

31. Hamauzu, Y., Yasui, H., Inno, T., Kume, C., Omanyuda, M. (2005). Phenolic profile, antioxidant property, and anti-influenza viral activity of Chinese quince (Pseudocydonia sinensis Schneid.), quince (Cydonia oblonga Mill.), and apple (Malus domestica Mill.) fruits. Journal of Agricultural and Food Chemistry, 53(4), 928-934.

https://doi.org/10.1021/jf0494635

32. Han, M., Li, G., Liu, X., Li, A., Mao, P., Liu, P., Li, H. (2019). Phenolic profile, antioxidant activity and anti-proliferative activity of crabapple fruits. Horticultural Plant Journal, 5(4), 155-163. https://doi.org/10.1016/j.hpj.2019.01.003

33. Hellstrom, J.K., Torronen, A.R., Mattila, P.H. (2009). Proanthocyanidins in common food products of plant origin. Journal of Agricultural and Food Chemistry, 57(17), 7899-7906. https://doi.org/10.1021/jf901434d

34. Hollands, W.J., Voorspoels, S., Jacobs, G., Aaby, K., Meisland, A., Garcia-Villalba, R., Tomas-Barberan, F., Piskuła, M.K., Mawson, D., Vovk, I., Needs, P.W., Kroon, P. (2017). Development, validation and evaluation of an analytical method for the determination of monomeric and oligomeric procyanidins in apple extracts. Journal of Chromatography A, 1495, 46-56. https://doi.org/10.1016/j.chroma.2017.03.030

35. Hollman, P.C., van Trijp, J.M., Buysman, M.N., van der Gaag, M.S., Mengelers, M.J., de Vries, J.H., Katan, M.B. (1997). Relative bioavailability of the antioxidant flavonoid quercetin from various foods in man. FEBS Letters, 418(1-2), 152-156. https://doi.org/10.1016/S0014-5793(97)01367-7

36. Horszwald, A., Andlauer, W. (2011). Characterization of bioactive compounds in berry juices by traditional photometric and modern microplate methods. Journal of Berry Research, 1 (4), 189-199.

https://doi.org/10.3233/JBR-2011-020

37. Jacob, K., Periago, M.J., Böhm, V., Berruezo, G.R. (2008). Influence of lycopene and vitamin $\mathrm{C}$ from tomato juice on biomarkers of oxidative stress and inflammation. British Journal of Nutrition, 99(1), 137-146.

https://doi.org/10.1017/S0007114507791894

38. Jakobek, L., García-Villalba, R., Tomás-Barberán, F.A. (2013). Polyphenolic characterization of old local apple varieties from Southeastern European region. Journal of Food Composition and Analysis, 31(2), 199-211.

https://doi.org/10.1016/j.jfca.2013.05.012

39. Jelodarian, S., Ebrahimabadi, A.H., Khalighi, A., Batooli, H. (2012). Evaluation of antioxidant activity of Malus domestica 
fruit extract from Kashan area. Avicenna Journal of Phytomedicine, 2(3), 139-145.

40. Jepson, R.G., Mihaljevic, L., Craig, J. (2004). Cranberries for preventing urinary tract infections. Cochrane Database of Systematic Reviews, 2, art. no. CD001321.

https://doi.org/10.1002/14651858.CD001321.pub3

41. Jiao, X., Wang, Y., Li, Y., Lang, Y., Li, E., Zhang, X., Zhang, Q., Feng, Y., Meng, X., Li, B. (2019). Blueberry polyphenols extract as a potential prebiotic with anti-obesity effects on C57BL/6 J mice by modulating the gut microbiota. Journal of Nutritional Biochemistry, 64, 88-100.

https://doi.org/10.1016/j.jnutbio.2018.07.008

42. Kahle, K., Kraus, M., Richling, E. (2005). Polyphenols profiles of apple juices. Molecular Nutrition \& Food Research, 49(8), 797-806. https://doi.org/10.1002/mnfr.200500064.

43. Knekt, P., Kumpulainen, J., Jarvinen, R., Rissanen, H., Heliovaara, M., Reunanen, A. (2002). Flavonoid intake and risk of chronic diseases. American Journal of Clinical Nutrition, 76(3), 560-568.

https://doi.org/10.1093/ajcn/76.3.560

44. Kolniak-Ostek, J., Oszmiański, J., Wojdyło, A. (2013). Effect of L-ascorbic acid addition on quality, polyphenolic compounds and antioxidant capacity of cloudy apple juices. European Food Research and Technology, 236(5), 777-798.

https://doi.org/10.1007/s00217-013-1931-z

45. Krawitzky, M., Arias, E., Peiro, J.M., Negueruela, A.J., Val, J., Oria, R. (2014). Determination of color, antioxidant activity, and phenolic profile of different fruit tissue of Spanish 'Verde Doncella' apple cultivar. International Journal of Food Properties, 17(10), 2298-2311.

https://doi.org/10.1080/10942912.2013.792829

46. Kschonsek, J., Wolfram, T., Stöckl, A., Böhm, V. (2018). Polyphenolic compounds analysis of old and new apple cultivars and contribution of polyphenolic profile to the in vitro antioxidant capacity. Antioxidants, 7(1), art. no. 20.

https://doi.org/10.3390/antiox7010020

47. Lee, K.W., Kim, Y.J., Kim, D.-O., Lee, H.J., Lee, Ch.Y. (2003). Major phenolics in apple and their contribution to the total antioxidant capacity. Journal of Agricultural and Food Chemistry, 51(22), 6516-6520.

https://doi.org/10.1021/jf034475w

48. Liu, Q., Tang, G-Y., Zhao, C.-N., Gan, R.-Y., Li, H-B. (2019). Antioxidant activities, phenolic profiles, and organic acids contents of fruit vinegars. Antioxidants, 8(4), art. no.78. https://doi.org/10.3390/antiox8040078

49. Lončarić A., Matanović K., Ferrer P., Kovač, T., Šarkanj, B., Skendrović Babojelić, M., Lores, M. (2020). Peel of traditional apple varieties as a great source of bioactive compounds: extraction by micro-matrix solid-phase dispersion. Foods, 9(1), art. no. 80 . https://doi.org/10.3390/foods9010080

50. Lotito, S.B., Frei, B. (2004a). Relevance of apple polyphenols as antioxidant in human plasma: contrasting in vitro and in vivo effects. Free Radical Biology \& Medicine, 36(2), 201-211. https://doi.org/10.1016/j.freeradbiomed.2003.10.005

51. Lotito, S.B., Frei, B. (2004b). The increase in human plasma antioxidant capacity after apple consumption is due to the metabolomics effect of fructose on urate, not apple-derived antioxidant flavonoids. Free Radical Biology \& Medicine, 37(2), 251-258.

https://doi.org/10.1016/j.freeradbiomed.2004.04.019
52. Lotito, S.B., Frei, B. (2006). Consumption of flavonoid-rich foods and increased plasma antioxidant capacity in humans: cause, consequence, or epiphenomena. Free Radical Biology \& Medicine, 41(12), 1727-1746.

https://doi.org/10.1016/j.freeradbiomed.2006.04.033

53. Loung, Ch.-Y., Fernando, W., Rupasingne, H.P.V., Hoskin, D.W. (2019). Apple peel flavonoid fraction 4 suppresses breast cancer cell growth by cytostatic and cytotoxic mechanisms. Molecules, 24(18), art. no. 3335 . https://doi.org/10.3390/molecules24183335

54. Lu, Y.R., Foo, L.Y. (2000). Antioxidant and radical scavenging activities of polyphenols from apple pomace. Food Chemistry, $68(1), 81-85$.

https://doi.org/10.1016/S0308-8146(99)00167-3

55. Maleki, S.J., Crespo, J.F., Cabanillas, B. (2019). Anti-inflammatory effects of flavonoids. Food Chemistry, 299, art. no. 125124. https://doi.org/10.1016/j.foodchem.2019.125124

56. Manach, C., Williamson, G., Morand, C., Scalbert, A., Remesy, C. (2005). Bioavailability and bioefficacy of polyphenols in humans: I. Review of bioavailability studies. American Journal of Clinical Nutrition, 81, 230-242.

https://doi.org/10.1093/ajcn/81.1.2305

57. Maragò, E., Iacopini, P., Camangi, F., Scattino, C., Ranieri, A., Stefani, A., Sebastiani, L. (2015). Phenolic profile and antioxidant activity in apple juice and pomace: effects of different storage conditions. Fruits, 70(4), 213-223. https://doi.org/10.1051/fruits/2015015

58. Martí, N., Mena, P., Cánovas, J.A., Micol, V., Saura, D. (2009). Vitamin $\mathrm{C}$ and the role of citrus juices as functional food. Natural Product Communications, 4(5), 677-700. https://doi.org/10.1177/1934578X0900400506

59. Matsuoka, K. (2019). Anthocyanins in apple fruit and their regulation for health benefits. In Flavonoid - a Coloring Model for Cheering Up Life, IntechOpen. Available on-line at: [cdn.intechopen.com/pdfs/66144.pdf] (accessed 11 February 2020). https://doi.org/10.5772/intechopen.85257

60. Minatel, I.O., Borges, C.V., Ferreira, M.J, Gomez Gomez, H.A., Chen, Ch.-Y.O., Pereira Lima, G.P. (2017). Phenolic compounds: functional properties, impact of processing and bioavailability. Eds. M. Soto-Hernandez, M. Palma-Tenango, M. del Rosaria Garcia-Mateos, In Phenolic Compounds. Biological Activity, IntechOpen, London, UK. https://doi.org/10.5772/66368

61. Murillo, E., Britton, G.B., Durant, A.A. (2012). Antioxidant activity and polyphenol content in cultivated and wild edible fruits grown in Panama. Journal of Pharmacy \& Bioallied Sciences, 4(4), 313-317. https://doi.org/10.4103/0975-7406.103261

62. Murphy, K.J., Walker, K.M., Dyer, K.A. (2019). Estimation of daily intake of flavonoids and major food sources in middleaged Australian men and women. Nutrition Research, 61, 64-81. https://doi.org/10.1016/j.nutres.2018.10.006

63. Murtaza, A., Iqbal, A., Marszałek, K., Iqbal, M.A., Waseem Ali Sh., Xu, X., Pan, Sh., Hu, W. (2020). Enzymatic, phyto-, and physicochemical evaluation of apple juice under highpressure carbon dioxide and thermal processing. Foods, 9(2), art. no. 243 .

https://doi.org/10.3390/foods9020243

64. Naczk, M., Shahidi, F. (2004). Extraction and analysis of phenolics in food. Journal of Chromatography A, 1054(1-2), 95-111. https://doi.org/10.1016/S0021-9673(04)01409-8 
65. Ohr, L.M. (2004). Dietary antioxidants. Food Technology, 58(10), 67-74.

66. Oszmianski, J., Wolniak, M., Wojdylo, A., Wawer, I. (2007). Comparative study of polyphenolic content and antiradical activity of cloudy and clear apple juices. Journal of the Science and Food Agriculture, 87(4), 573-579.

https://doi.org/10.1002/jsfa.2707

67. Oszmiański, J., Wojdyło, A. (2009). Effects of blackcurrant and apple mash blending on the phenolics contents, antioxidant capacity, and color of juices. Czech Journal of Food Sciences, 27(5), 338-351. https://doi.org/10.17221/20/2008-CJFS

68. Oszmiański, J., Wolniak, M., Wojdyło, A., Wawer, I. (2008). Influence of apple puree preparation and storage on polyphenols contents and antioxidant activity. Food Chemistry, 107(4), 1473-1484. https://doi.org/10.1016/j.foodchem.2007.10.003

69. Pająk, P., Socha, R., Łakoma, P., Fortuna, T. (2017). Antioxidant properties of apple slices stored in starch-based films. International Journal of Food Properties, 20(5), 1117-1128.

https://doi.org/10.1080/10942912.2016.1203931

70. Pastene, E., Troncoso, M., Figueroa, G., Alarcon, J., Speisky, H. (2009). Association between polymerization degree of apple peel polyphenols and inhibition of Helicobacter pylori urease. Journal of Agricultural and Food Chemistry, 57(2), 416-424.

https://doi.org/10.1021/jf8025698

71. Pavun, L., Usković-Marković, S., Jelikić-Stankov, M., Đikanović, D., Đurđević, P. (2018). Determination of flavonoids and total polyphenol contents in commercial apple juices. Czech Journal of Food Sciences, 36(3), 233-238.

https://doi.org/10.17221/211/2017-CJFS

72. Pires, T.C.S.P., Dias, M.I., Barros, L., Alves, M.J., Oliveira, M.B.P.P., Santos-Buelga, C., Ferreira, I.C.F.R. (2018). Antioxidant and antimicrobial properties of dried Portuguese apple variety (Malus domestica Borkh. cv Bravo de Esmolfe). Food Chemistry, 240, 701-706.

https://doi.org/10.1016/j.foodchem.2017.08.010

73. Plumb, G.W., De Pascual-Teresa, S., Santos-Buelga, C., Cheynier, V., Williamson, G. (1998). Antioxidant properties of catechins and proanthocyanidins: Effect of polymerisation, galloylation and glycosylation. Free Radical Research, 29(4), 351-358. https://doi.org/10.1080/10715769800300391

74. Porrini, M., Riso, P. (2008). Factors influencing the bioavailability of antioxidants in foods: a critical appraisal. Nutrition, Metabolism \& Cardiovascular Diseases, 18(10), 647-650. https://doi.org/10.1016/j.numecd.2008.08.004

75. Rana, Sh., Gupta, S., Rana, A., Bushau, S. (2015). Functional properties, phenolic constituents and antioxidant potential of industrial apple pomace for utilization as active food ingredient. Food Science and Human Wellness, 4(4), 180-187. https://doi.org/10.1016/j.fshw.2015.10.001

76. Raphaelli, C.D., Pereira, E.D., Camargo, T.M., Vinholes, J., Rombaldi, C.V., Vizzotto, M., Nora, L. (2019). Apple phenolic extracts strongly inhibit $\alpha$-glucosidase activity. Plant Foods for Human Nutrition, 74(3), 430-435.

https://doi.org/10.1007/s11130-019-00757-3

77. Raudone, L., Raudonis, R., Liaudanskas, M., Janulis, V., Viskelis, P. (2017). Phenolic antioxidant profiles in the whole fruit, flesh and peel of apple cultivars grown in Lithuania. Scientia Horticulturae, 216, 186-192.

https://doi.org/10.1016/j.scienta.2017.01.005
78. Raudone, L., Raudonis, R., Liaudanskas, M., Viškelis, P., Pukalskas, A., Janulis, V. (2016). Phenolic profiles and contribution of individual compounds to antioxidant activity of apple powders. Journal of Food Science, 81 (5), C1055-C1061. https://doi.org/10.1111/1750-3841.13277

79. Rios, L.Y., Gonthier, M.P., Rémésy, C., Mila, I., Lapierre, C., Lazarus, S.A., Williamson, G., Scalbert, A. (2003). Chocolate intake increases urinary excretion of polyphenol-derived phenolic acids in healthy human subjects. American Journal of Clinical Nutrition, 77(4), 912-918.

https://doi.org/10.1093/ajcn/77.4.912

80. Saenger, T., Hűbner F., Humpf, H.-U. (2017). Short-term biomarkers of apple consumption. Molecular Nutrition \& Food Research, 61 (3), art. no. 1600629.

https://doi.org/10.1002/mnfr.201600629

81. Salucci, S., Falcieri, E. (2020). Polyphenol and their potential role in preventing skeletal muscle atrophy. Nutrition Research, 74, $10-22$.

https://doi.org/10.1016/j.nutres.2019.11.004

82. Santarelli, V., Neri, L., Sacchetti, G., Di Mattia, C.D., Mastrocola, D., Pittia, P. (2020). Response of organic and conventional apples to freezing and freezing pre-treatments: focus on polyphenols content and antioxidant activity. Food Chemistry, 308, art. no. 125570 .

https://doi.org/10.1016/j.foodchem.2019.125570

83. Scalbert, A., Williamson, G. (2000). Dietary intake and bioavailability of polyphenols. Journal of Nutrition, 130(8), 2073S-2085S. https://doi.org/10.1093/jn/130.8.2073S

84. Schempp, H., Christof, S., Mayr, U., Treutter, D. (2016). Phenolic compounds in juices of apple cultivars and their relation to antioxidant activity. Journal of Applied Botany and Food Quality, $89,11-20$.

85. Serra, A., Macia, A., Romero, M.P., Valls, J., Blade, C., Arola, L., Motilva, M.J. (2010). Bioavailability of procyanidin dimers and trimers and matrix food effects in in vitro and in vivo models. British Journal of Nutrition, 103, 944-952.

https://doi.org/10.1017/S0007114509992741

86. Shahidi, F., Ambigaipalan, P. (2015). Phenolics and polyphenolics in foods, beverages and spices: antioxidant activity and health effects - a review. Journal of Functional Foods, 18, Part B, 820-897.

https://doi.org/10.1016/j.jff.2015.06.018

87. Skinner, R.Ch., Gigliotti, J.C., Ku, K.M., Tou, J.C. (2018). A comprehensive analysis of the composition, health benefits, and safety of apple pomace. Nutrition Reviews, 76(12), 893-909. https://doi.org/10.1093/nutrit/nuy033

88. Skłodowska, M., Mikiciński, A., Wielanek, M., Kuźniak, E., Sobiczewski, P. (2018). Phenolic profiles in apple leaves and the efficiency of selected phenols against free blight (Erwinia amylovera). European Journal of Plant Pathology, 151 (1), 213-228. https://doi.org/10.1007/s10658-017-1368-5

89. Spranger, I., Sun, B., Mateus, A.M., de Freitas, V., Ricardo-DaSilva, J.M. (2008). Chemical characterization and antioxidant activities of oligomeric and polymeric procyanidin fractions from grape seeds. Food Chemistry, 108(2), 519-532.

https://doi.org/10.1016/j.foodchem.2007.11.004

90. Stan, A., Bujor, O.-C., Badulescu, L. (2017). Extraction of phenolic compounds from organic dried apples: comparison between conventional, microwave- and ultrasound- assisted extrac- 
tion methods. Journal of Horticulture, Forestry and Biotechnology, $21(3), 8-14$.

91. Starowicz, M. (2019). Food and Nutritional Analysis. In Encyclopedia of Analytical Science (third edition), Elsevier, London, UK, pp. 265-270.

92. Sun, J., Chu, Y.-F., Wu, X.Z., Liu, R.H. (2002). Antioxidant and antiproliferative activities of common fruits. Journal of Agricultural and Food Chemistry, 50(25), 7449-7454. https://doi.org/10.1021/jf0207530

93. Sut, S., Zengin, G., Maggi, F., Malagoli, M., Dall'Acqua, S. (2019). Triterpene acid and phenolics from ancient apples of Friuli Venezia Giulia as nutraceutical ingredients: LC-MS study and in vitro activities. Molecules, 24(6), art. no. 1109. https://doi.org/10.3390/molecules24061109

94. Średnicka-Tober, D., Kazimierczak, R., Rembiałowska, E., Strok, T., Świąder, K., Hallmann, E. (2017). Bioactive compounds in organic apple juices enriched with chokeberry and green tea extract. Journal of Research and Applications in Agricultural Engineering, 62(4), 173-177.

95. Tappi, S., Ramazzina, I., Rizzi, F., Sacchetti, G., Ragni, L., Rocculi, P. (2018). Effect of plasma exposure time on the polyphenolic profile and antioxidant activity of fresh-cut apples. Applied Sciences - Basel, 8(10), art. no. 1939.

https://doi.org/10.3390/app8101939

96. Tian, Y., Sun, L., Yang, Y., Gou, X., Niu, P., Guo, Y. (2018). Changes in the physicochemical properties, aromas and polyphenols of not from concentrate (NFC) apple juice during production. CyTA - Journal of Food, 16(1), 755-764. https://doi.org/10.1080/19476337.2018.1471102

97. Verdu, C.F., Childebrand, N., Marnet, N., Lebail, G., Dupuis, F., Laurens, F., Guilet, D., Guyot, S. (2014). Polyphenol variability in the fruits and juices of a cider apple progeny. Journal of the Science of Food and Agriculture, 94(7), 1305-1314.

https://doi.org/10.1002/jsfa.6411

98. Wang, H.L, Guo, X.B, Hu, X.D, Li, T., Fu, X., Liu, R.H. (2017). Comparison of phytochemical profiles, antioxidant and cellular antioxidant activities of different varieties of blueberry (Vaccinium spp.). Food Chemistry, 217, 773-781.

https://doi.org/10.1016/j.foodchem.2016.09.002

99. Wang, J., Wang, J., Ye, J.H., Vanga, S.K., Raghavan, V. (2019b). Influence of high-intensity ultrasound on bioactive compound of strawberry juice: profiles of ascorbic acid, phenolics, antioxidant activity and microstructure. Food Control, 96, 128-136. https://doi.org/10.1016/j.foodcont.2018.09.007

100. Wang, Y., Zhao, H., Deng, H., Song, X., Zhang, W., Wu, S., Wang, J. (2019a), Influence of pretreatments on microwave vacuum drying kinetics, physicochemical properties and sensory quality of apple slices. Polish Journal of Food and Nutrition Sciences, 69(3), 297-306. https://doi.org/10.31883/pjfns/110734

101. WHO (2009). Fruits, vegetables and NCD disease prevention. Available on-line at: [https://www.who.int/dietphysicalactivity/ media/en/gsfs_fv.pdf] (accessed 9 September 2020).

102. Whyte, A.R., Williams, C.M. (2011). The effect on memory of an acute blueberry flavonoid intervention with 8-9-year-old children. Appetite, 57(2), art. no. 567 https://doi.org/10.1016/j.appet.2011.05.099

103. Williamson, G., Kay, C.D., Crozier, A. (2018). The bioavailability, transport, and bioactivity of dietary flavonoids: a review from a historical perspective. Comprehensive Reviews in Food Science and Food Safety, 17(5), 1054-1112.

https://doi.org/10.1111/1541-4337.12351

104. Wojdyło, A., Oszmiański, J., Bielicki, P. (2010). Chemical composition, phenolic compounds and antioxidant activity of three varieties of apple from organic and conventional farming. Journal of Research and Applications in Agricultural Engineering, 55(4), 173-177.

105. Wojdyło, A., Oszmiański, J., Laskowski, P. (2008). Polyphenolic compounds and antioxidant activity of new and old apple varieties. Journal of Agricultural and Food Chemistry, 56(15), 6520-6530. https://doi.org/10.1021/jf800510j

106. Wruss, J., Lanzerstorfer, P., Huemer, S., Himmelsbach, M., Mangge, H., Höglingen, O., Weghuber, D., Weghuber, J. (2015). Differences in pharmokinetics of apple polyphenols after standardized oral consumption of unprocessed apple juice. Nutritional Journal, 14, art. no. 32. https://doi.org/10.1186/s12937-015-0018-z

107. Xu, Y., Fan, M., Ran, J., Zhang, T., Sun, H., Dong, M., Zhang, Z., Zheng, H. (2016). Variation in phenolic compounds and antioxidant activity in apple seeds of seven cultivars. Saudi Journal of Biological Sciences, 23(3), 379-388. https://doi.org/10.1016/j.sjbs.2015.04.002

108. Yuste, S., Ludwig, I.A., Rubio, L., Romero, M.P., Pedret, A., Valls, R.M., Sola, R., Motilva, M.J., Macia, A. (2019). In vivo biotransformation of (poly)phenols and anthocyanins of redfleshed apple and identification of intake biomarkers. Journal of Functional Foods, 55, 146-155. https://doi.org/10.1016/j.jff.2019.02.013

109. Yuste, S., Macia, A., Ludwig, I.A., Romero, M.P., Fernandez-Castillejo, S., Catalan, U., Motilva, M.J., Rubio, L. (2018). Validation of dried blood spot cards to determine apple phenolic metabolites in human blood and plasma after an acute intake of red-fleshed apple snack. Molecular Nutrition \& Food Research, 62(23), art. no. 1800623.

https://doi.org/10.1002/mnfr.201800623

110. Zeng, X., Du, Z., Ding, X., Jiang, W. (2020). Characterization of the direct interaction between apple condensed tannins and cholesterol in vitro. Food Chemistry, 309, art. no. 125762. https://doi.org/10.1016/j.foodchem.2019.125762

111. Zhang, M., Wang, Z., Mao, Y., Hu, Y., Yang, L. Wang, Y. (2019). Effects of quince pollen pollination on fruit qualities and phenolic substance contents of apples. Scientia Horticulturae, 256, art. no. 108628.

https://doi.org/10.1016/j.scienta.2019.108628

112. Zhou, H.C., Tam, N.F.Y., Lin, Y.M., Ding, Z.H., Chai, W.M., Wei, S.D. (2014). Relationships between degree of polymerization and antioxidant activities: a study on proanthocyanidins from the leaves of a medicinal mangrove plant Ceriops tagal. PLoS ONE, 9(10), art. no. e107606. https://doi.org/10.1371/journal.pone.0107606

113. Zielinski, A.A.F., Alberti, A., Braga, C.M., da Silva, K.M., Canteri, M.H.G., Igarashi-Mafra, L., Granato, D., Nogueira, A., Wosiacki, G. (2014). Effect of mash maceration and ripening stage of apples on phenolic compounds and antioxidant power of cloudy juices: a study using chemometrics. LWT - Food Science and Technology, 57(1), 223-229.

https://doi.org/10.1016/j.Iwt.2014.01.029 
114. Zielińska, D., Laparra-Llopis, J.M., Zieliński, H., Szawara-Nowak, D., Giménez-Bastida, J.A. (2019). Role of apple phytochemicals, phloretin and phloridzin, in modulating processes related to intestinal inflammation. Nutrients, $11(5)$, art. no. 1173 . https://doi.org/10.3390/nu11051173

115. Zou, Y., Wang, T., Li, Sh., Liu, Y., You, J. (2020). Dietary apple polyphenols promote fat browning in high-fat diet-induced obese mice through activation of adenosine monophosphate- activated protein kinase $\alpha$. Journal of the Science of Food and Agriculture, 100(6), 2389-2398.

https://doi.org/10.1002/jsfa.10248

Submitted: 15 April 2020. Revised: 12 July and 10 September 2020. Accepted: 18 September 2020. Published on-line: 15 October 2020. 